\title{
De invloed van vraagfactoren op de markt voor leerovereenkomsten
}

Citation for published version (APA):

de Grip, A., Heijke, J. A. M., \& Lodder, B. J. H. (1992). De invloed van vraagfactoren op de markt voor leerovereenkomsten. Researchcentrum voor Onderwijs en Arbeidsmarkt, Faculteit der Economische Wetenschappen. ROA Research Memoranda No. 3 https://doi.org/10.26481/umaror.1992003

Document status and date:

Published: 01/01/1992

DOI:

10.26481/umaror.1992003

Document Version:

Publisher's PDF, also known as Version of record

\section{Please check the document version of this publication:}

- A submitted manuscript is the version of the article upon submission and before peer-review. There can be important differences between the submitted version and the official published version of record.

People interested in the research are advised to contact the author for the final version of the publication, or visit the DOI to the publisher's website.

- The final author version and the galley proof are versions of the publication after peer review.

- The final published version features the final layout of the paper including the volume, issue and page numbers.

Link to publication

\footnotetext{
General rights rights.

- You may freely distribute the URL identifying the publication in the public portal. please follow below link for the End User Agreement:

www.umlib.nl/taverne-license

Take down policy

If you believe that this document breaches copyright please contact us at:

repository@maastrichtuniversity.nl

providing details and we will investigate your claim.
}

Copyright and moral rights for the publications made accessible in the public portal are retained by the authors and/or other copyright owners and it is a condition of accessing publications that users recognise and abide by the legal requirements associated with these

- Users may download and print one copy of any publication from the public portal for the purpose of private study or research.

- You may not further distribute the material or use it for any profit-making activity or commercial gain

If the publication is distributed under the terms of Article $25 \mathrm{fa}$ of the Dutch Copyright Act, indicated by the "Taverne" license above, 


\section{DE INVLOED VAN VRAAGFACTOREN OP DE MARKT VOOR LEEROVEREENKOMSTEN}

ROA-RM-1992/3

A. de Grip, J.A.M. Heijke, B.J.H. Lodder

Faculteit der Economische Wetenschappen

Rijksuniversiteit Limburg

Maastricht, mei 1992 
CIP-GEGEVENS KONINKLIJKE BIBLIOTHEEK, DEN HAAG

Grip, A. de

De invloed van vraagfactoren op de markt voor leerovereenkomsten / A. de Grip, J.A.M. Heijke, B.J.H. Lodder. - Maastricht: Researchcentrum voor Onderwijs en Arbeidsmarkt, Faculteit der Economische Wetenschappen, Rijksuniversiteit Limburg. - (Research memorandum I Researchcentrum voor Onderwijs en Arbeidsmarkt ; 1992/3)

Met lit. opg.

ISBN 90-5321-083-0 in spiraalband

Trefw.: leerlingwezen. 
INHOUDSOPGAVE

bladzijde

SAMENVATTING i

1. INLEIDING

2. DE VRAAG NAAR LEEROVEREENKOMSTEN

2.1. Inleiding 4

2.2. Determinanten van de vraag 5

2.3. Econometrische modellering $\quad 8$

3. SCHATTINGSRESULTATEN 10

3.1. Inleiding 10

3.2. Primaire leerovereenkomsten 10

3.3. Voortgezette leerovereenkomsten 12

3.4. Bespreking van de resultaten per sector $\quad 14$

4. CONCLUSIES 15

$\begin{array}{ll}\text { LITERATUUR } & 17\end{array}$ 


\section{SAMENVATTING}

Op de markt voor leerovereenkomsten in het leerlingwezen spelen zowel vraag- als aanbodfactoren een rol. In deze studie is onderzocht in hoeverre de ontwikkeling van het aantal leerovereenkomsten te verklaren is met behulp van louter vraagfactoren. Uit de resultaten blijkt dat gewoontevorming bij bedrijven een belangrijke rol speelt in de vraag naar leerovereenkomsten. Uit de schattingsresultaten blijkt niet dat andere factoren, zoals de bezettingsgraad in bedrijven en de kapitaal-arbeidsratio een belangrijke rol spelen. Hoewel de vergoedingen die in het kader van de Bijdrageregeling Vakopleiding Jeugdigen (BVJ) plaatsvinden een significante invloed uitoefenen op de vraag naar leerovereenkomsten, blijkt uit de vraagelasticiteit met betrekking tot de genoemde regeling dat het om een relatief gering kwantitatief effect gaat. 


\section{INLEIDING}

De deelname aan een specifieke vorm van vervolgonderwijs wordt in de regel voorspeld door de omvang van de uitstroom uit de verschillende vooropleidingen te relateren aan een geschat instroompercentage. Zo wordt bijvoorbeeld bij de volumeraming van het aantal eerstejaars studenten door de Taakgroep Studentenraming (1990) de uitstroom uit het VWO vermenigvuldigd met het percentage leerlingen van het VWO dat in het voorafgaande jaar is gaan studeren. Hoewel deze procedure geen foutloze voorspellingen oplevert, concluderen Oosterbeek, Teulings en Webbink (1991) dat een dergelijke prognosetechniek goed stand houdt in vergelijking met prognoses op basis van causale modellen.

Voor de voorspelling van de ontwikkeling van het aantal leerovereenkomsten is deze procedure echter enigszins onbevredigend, omdat geen rekening wordt gehouden met de economische ontwikkelingen die van invloed kunnen zijn op het aantal leerovereenkomsten. Zo is er in het verleden sprake geweest van een tekort aan praktijkplaatsen als gevolg van economische recessies. Uit figuur 1 blijkt dat het aantal primaire en voortgezette leerovereenkomsten een aanzienlijke daling te zien geeft in de recessieperioden rond de jaren 1975 en 1982.

Voor het tot stand komen van een leerovereenkomst is het nodig dat een bedrijf een praktijkplaats aanbiedt en dat een leerling die praktijkplaats wenst te bezetten. In overeenstemming met deze gedachtengang zou men kunnen spreken over het aanbod van praktijkplaatsen door bedrijven en de vraag naar praktijkplaatsen door leerlingen. In deze studie is er echter voor gekozen om aansluiting te zoeken bij de terminologie van de economische arbeidsmarkttheorie. Daarbij wordt met het aanbod van arbeid het aanbod van werknemers bedoeld. De vraag heeft dan betrekking op de vraag naar werknemers door werkgevers. Analoog hieraan wordt gesproken van de vraag naar leerlingen door bedrijven (het aanbod van prakijkplaatsen) en het aanbod van leerlingen (de vraag naar prakijkplaatsen door leerlingen).

In beginsel zou bij de specificatie van een model, waarin een causale verklaring wordt gegeven van de ontwikkeling van het aantal leerovereenkomsten, rekening moeten worden gehouden met zowel vraag- als aanbodfactoren. Problematisch daarbij is dat zowel de vraag als het aanbod niet worden waargenomen', maar alleen het feitelijk aantal leerovereenkomsten.

1. De CBS-gegevens van het totaal aantal leerlingen in het leerlingwezen (inclusief degenen zonder leerovereenkomst) zouden in beginsel kunnen worden opgevat als het aanbod. Deze gegevens sluiten echter niet goed aan bij de CBS-gegevens van het aantal afgesloten leerovereenkomsten. Voor een aantal waarnemingsjaren blijkt het aantal afgesloten leerovereenkomsten zelfs groter te zijn dan het totaal aantal leerlingen in het leerlingwezen en deeltijd-KMBO. 

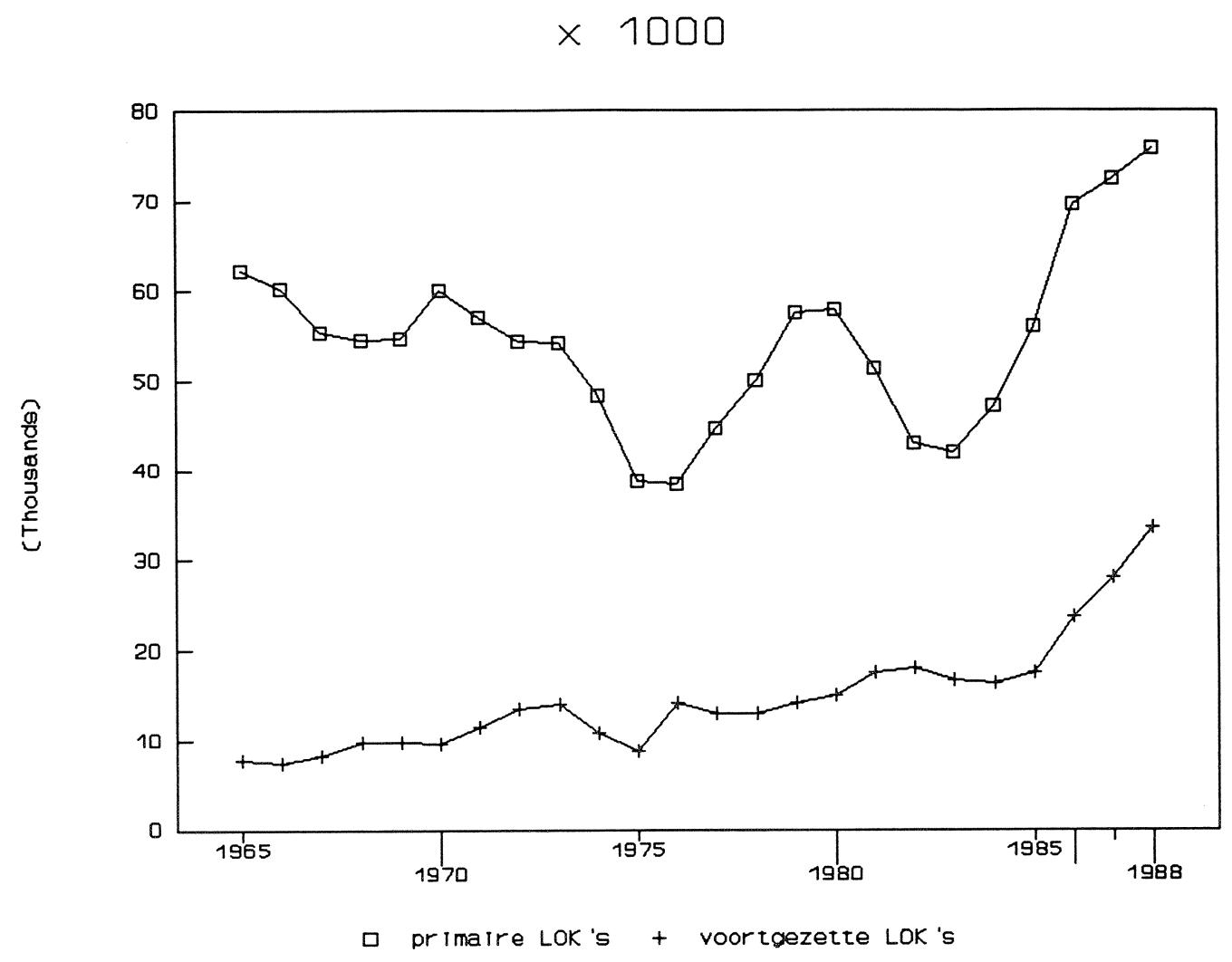

Bron: CBS/ROA

Hoewel het in principe mogelijk is een dergelijk model te schatten, wordt in de literatuur gewezen op een aantal problemen die de praktische relevantie van de methode beperkt (Maddala, 1983; Kooiman en Kloek, 1979).

Derhalve is er door ons voor gekozen om het onderzoek naar de ontwikkeling van het aantal leerovereenkomsten in enkele stappen te faseren. In een eerdere studie is met zogenaamde 'fractiemodellen' het aantal leerovereenkomsten verklaard uit de ontwikkeling van het aantal leerlingen. (Lodder, De Grip, Heijke, 1992). De verandering van totaal aantal leerovereenkomsten werd daarbij allereerst uitgesplitst in een in- en uitstroom van leerlingen. De instroom werd vervolgens verklaard op basis van de uitstroom uit het LTO/ITO, LHNO/IHNO en de MAVO. De uitstroom werd tenslotte verklaard op basis van het aantal in de voorgaande jaren ingestroomde leerlingen. De fracties werden op basis van tijdreeksen geschat. Bij deze 
benadering staat dus het aanbod van leerlingen centraal.

In aanvulling op bovengenoemde studie wordt in deze studie onderzocht in hoeverre vraagfactoren van invloed zijn op het aantal afgesloten leerovereenkomsten. Daarbij wordt gekeken naar de invloed van het subsidiebeleid van de overheid (Bijdrageregeling Vakopleiding Jongeren, BVJ), conjuncturele fluctuaties, de technologische ontwikkeling en andere structurele factoren. Zoals gezegd, is het in principe mogelijk een model met zowel aanbod- als vraagfactoren te schatten. Hierop zal in het laatste hoofdstuk worden teruggekomen.

In de hier gepresenteerde analyse zal dus volledig worden afgezien van de invloed van aanbodfactoren bij de verklaring van het aantal leerovereenkomsten. In beginsel hoeft dit niet onrealistisch te zijn. Als het aantal leerovereenkomsten over een groot deel van de waarnemingsperiode vraaggeïnduceerd is, dan zijn het met name vraagfactoren leconomische variabelen) die het aantal leerovereenkomsten verklaren. In tijden van laagconjunctuur werd een tekort aan praktijkplaatsen geconstateerd, zodat in die periode het aantal leerovereenkomsten duidelijk vraaggeinduceerd is geweest. Voor de overige jaren in de waarnemingsperiode (19681988) blijft de veronderstelling realistisch voorzover de vraag naar leerlingen het aanbod niet heeft overtroffen. Frietman en Hövels (1990) wijzen er evenwel op dat op de markt voor leerovereenkomsten recentelijk een omslag heeft plaatsgevonden: "Die omslag betreft de verhouding tussen aanbod en vraag naar praktijkplaatsen. De aantrekkende economie, demografische ontwikkelingen en ook de getalsmatige aderlating die met name het LBO ondergaat, hebben een tekort aan prakijkopleidingsplaatsen langzamerhand doen omslaan in een tekort aan leerlingen". Dit impliceert dat verwacht mag worden dat het schatten van een model met louter vraagfactoren op een dataset met waarnemingen uit de periode 1965-1989, dus voor de genoemde omslag, redelijk goede resultaten oplevert, maar waarschijnlijk minder adequaat is voor het prognosticeren van de ontwikkelingen in de eerste helft van de jaren ' 90 .

De verdere opbouw van deze studie is als volgt. In hoofdstuk 2 wordt het ontwikkelde model geformuleerd. Allereerst wordt in dit hoofdstuk het vraagbegrip nader uitgewerkt. Vervolgens worden de determinanten van de vraag besproken, waarna wordt ingegaan op de econometrische modellering. In hoofdstuk 3 worden de schattingsresultaten besproken, waarbij achtereenvolgens wordt ingegaan op de primaire en de voortgezette leeroverkomsten. In hoofdstuk 4 wordt een aantal conclusies getrokken. 


\section{DE VRAAG NAAR LEEROVEREENKOMSTEN}

\subsection{Inleiding}

De invloed van de economische ontwikkeling op het aantal leerovereenkomsten kan het beste worden geanalyseerd op het niveau van bedrijfssectoren, waaraan de opleidingssectoren binnen het leerlingwezen in meer of mindere mate nauw zijn gerelateerd. Daarom zijn de aantallen leeroverkomsten die zijn afgesloten binnen de 28 landelijke opleidingsorganen geaggregeerd tot 10 (opleidings-)sectoren, zoals die door het CPB (1990) worden onderscheiden. Deze opleidingsen bedrijfssectoren worden in tabel 2.1 weergegeven.

Tabel 2.1. Overzicht van opleidingssectoren in relatie tot bedrijfssectoren
Opleidingssectoren
Bedrijfssectoren

Metaalverwerkende en

electronische sector

Bouw- en houtsector

Consumptieve sector

Administratieve sector

Grafische sector

Transportsector

Procesindustrie (VAPRO)

Textiel- en kledingsector

Dienstverlenende sector

Verzorgende sector (OVDB)

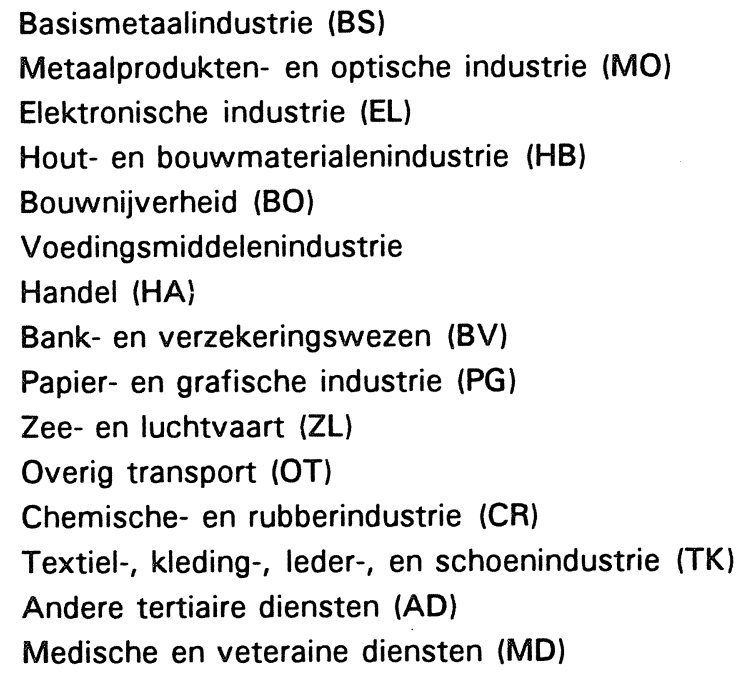

Voor een juiste modelspecificatie, is het nodig een goed beeld te hebben van de te verklaren variabele: het aantal leerovereenkomsten. Veronderstel dat er $T_{s, t-1}$ leerovereenkomsten zijn in sector $S$ in het jaar $t-1$. Het aantal leerovereenkomsten in sector $S$ in het jaar $t$ is dan per definitie gelijk aan $T_{s, t-1}$, vermeerderd met het aantal nieuw afgesloten leerovereenkomsten in dat jaar, $N_{s, t}$, en verminderd met het aantal beëindigde leerovereenkomsten, $E_{s, t}$. Het aantal beëindigde leerovereenkomsten kan daarbij worden opgesplitst in voortijdig beëindigde leerovereenkomsten, $P_{s, t}$ en leerovereenkomsten die beëindigd zijn vanwege het behalen van een certificaat of diploma, $\mathrm{C}_{\mathrm{s}, \mathrm{t}}$. In formulevorm kan dit worden genoteerd als:

$T_{s, t}=T_{s, t-1}+N_{s, t}-E_{s, t}$ 
$E_{s, t}=C_{s, t}+P_{s, t}$

Op basis hiervan wordt de verandering van het aantal leerovereenkomsten gedefinieerd als:

$D_{s, t}=T_{s, t}-T_{s, t-1}$

Op voorhand is niet duidelijk of economische variabelen gezien moeten worden als verklarende variabelen voor het totaal, $T_{s, t}$ het aantal nieuwe, $N_{s, t}$ of de verandering van het aantal leerovereenkomsten, $D_{s, t}$. Daarvoor is allereerst een nadere beschouwing van het begrip vraag noodzakelijk.

De totale vraag naar leerovereenkomsten, kan worden uitgesplitst in de uitbreidings- en vervangingsvraag. De som van de uitbreidings- en vervangingsvraag is gelijk aan het aantal 'jobopenings (De Grip, Heijke en Dekker, 1989). Analoog daaraan zou men met betrekking tot de leerovereenkomsten kunnen spreken van 'LOK-openings'. Het aantal nieuwe leerovereenkomsten, $\mathrm{N}_{\mathrm{s}, \mathrm{t}}$ is zodoende gelijk aan de som van de uitbreidings- en vervangingsvraag. De vervangingsvraag is dan gelijk aan het aantal leerlingen dat een leerovereenkomst beëindigt en de uitbreidingsvraag is gelijk aan de verandering van het aantal leerovereenkomsten:

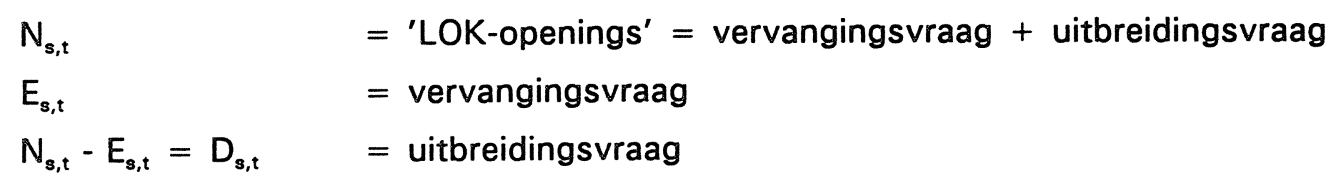

Economische variabelen worden in arbeidsmarktmodellen doorgaans gerelateerd aan de uitbreidingsvraag of de verandering van de werkgelegenheid (De Galan, 1981). Analoog hieraan kunnen in het te ontwikkelen model van leerovereenkomsten de economische variabelen worden gerelateerd aan het totaal aantal leerovereenkomsten, $T_{s, t}$ of de verandering van het aantal leerovereenkomsten $D_{s, t}$.

\subsection{Determinanten van de vraag}

Hövels (1985) heeft een onderzoek verricht naar het 'aanbod van leerarbeidsplaatsen' door bedrijven. De resultaten van deze studie zijn echter niet direct bruikbaar voor het formuleren van een vraagmodel op sectorniveau. De studie van Dekker, De Grip en Heijke (1990) biedt wel aanknopingspunten voor de formulering van het model. Aangezien een leerovereenkomst een specifiek type arbeidscontract betreft, is een vergelijking met de aandelen van beroepsklassen in het beroepenmodel van Dekker c.s. gerechtvaardigd, temeer daar in de laatstgenoemde studie eveneens wordt verondersteld dat de beroepenstructuur van de werkgelegenheid vraaggeïnduceerd is, hetgeen ook hier het uitgangspunt is. Dekker c.s. onderscheiden de volgende vier factoren die van invloed kunnen zijn op de (beroepen) structuur van de 
werkgelegenheid:

- de ontwikkeling van de loonkosten;

- de technologische ontwikkeling;

- overige bedrijfstak gebonden structurele factoren;

- bedrijfstak gebonden conjuncturele factoren.

De eerste factor, de ontwikkeling van de loonkosten, wordt door Dekker c.s. niet verder in beschouwing genomen. Verondersteld wordt dat de invloed van de loonstructuur constant is. Daarbij wordt gewezen op complicaties bij de modellering vanwege het feit dat het loon zowel een vraag- als aanbodfactor is. In deze studie wordt overigens wel een variabele gespecificeerd die mede bepalend is voor de prijs van arbeid, namelijk de omvang van de subsidie die in het kader van de Bijdrageregeling Vakopleiding Jeugdigen wordt gegeven aan bedrijven (de BVJsubsidie). Deze subsidieregeling is van kracht sinds 1983 . Het betreft een bedrag per praktijkplaats. De hoogte van de subsidie hangt niet af van het aanbod van leerlingen, en kan derhalve als exogene variabele in het model worden opgenomen ${ }^{2}$.

Voor de specificering van de variabele die de invloed van de technologische ontwikkeling op het aantal leerovereenkomsten weergeeft, is enigszins afgeweken van de door Dekker c.s. gebruikte variabele, door het structurele effect van de investeringen niet te relateren aan de toegevoegde waarde, maar aan het arbeidsvolume, gecorrigeerd voor conjunctuurschommelingen. Deze variabele vormt zodoende een benadering van de kapitaal-arbeidsratio van het produktieproces in een bedrijfssector en kan derhalve worden beschouwd als een indicator van de technologische ontwikkeling. De variabele is als volgt gedefinieerd ${ }^{3}$ :

2. De BVJ-variabele is als volgt geconstrueerd. Het totale bedrag dat beschikbaar is voor de subsidieregeling is gedeeld door het streefcijfer met betrekking tot het aantal leerlingen. Dit quotiënt is beschouwd als een redelijke benadering van het bedrag dat per praktijkplaats beschikbaar is. Vanaf 1983 heeft de variabele een waarde van rond de $f 4.500,-$. Aangezien de regeling pas vanaf de 1983 van kracht is, is de (logaritmisch getransformeerde) variabele voor de periode 1965-1982 op nul gesteld.

3. De cijfers over de ontwikkeling van de investeringen, het arbeidsvolume en de toegevoegde waarde zijn afkomstig van het CPB(1990). 


$$
\mathrm{TECH}_{s, t}=\frac{\sum_{j=-9}^{0} I N V E S T_{s, t+j}}{\sum_{j=-2}^{+2} A R B V_{s, t+j}}
$$

waarbij:

$I_{\text {INVEST }}=$ de investeringen in bedrijfstak $s$ in jaar $\mathrm{t}$ in prijzen van 1980.

$A R B V_{s, t} \quad=$ het arbeidsvolume in 1000 mensjaren in sector $s$ in jaar $\mathrm{t}$.

De invloed van bedrijfstakspecifieke conjuncturele factoren, wordt in navolging van Dekker c.s., weergegeven door een indicator van de bezettingsgraad van de produktiecapaciteit. De variabele is als volgt gedefinieerd:

$B E Z_{s, t}=\frac{T W_{s, t}}{\frac{1}{5} \sum_{j=-2}^{+2} T W_{s, t+j}}$

waarbij:

$T W_{s, t}=$ de toegevoegde waarde in sector $s$ in jaar $t$ in prijzen van 1980

De hoogte van het arbeidsvolume heeft een structureel effect op het aantal leerovereenkomsten. Deze variabele geeft inzicht in de omvang van de totale gerealiseerde arbeidsvraag van de desbetreffende bedrijfssector. Vanwege de te verwachten multicollineairiteitsproblemen is er voor gekozen om het aantal leerovereenkomsten te schalen met het arbeidsvolume. Vanuit de aannemelijke veronderstelling dat het aantal leerovereenkomsten in een bepaalde bedrijfssector recht evenredig verandert met de omvang van de werkgelegenheid in de desbetreffende sector, kan het aantal leerovereenkomsten als volgt worden gespecificeerd:

$T_{s, t}=W_{s, t} * F\left(X_{s, t}, \theta_{s}\right)$

ofwel:

$Y_{s, t}=\frac{T_{s, t}}{W_{s, t}}=F\left(X_{s, t}, \theta_{s}\right)$

met:

$T_{s, t} \quad=$ totaal aantal leerovereenkomsten in sector $\mathrm{s}$ in jaar $\mathrm{t}$

$W_{s, t} \quad=$ arbeidsvolume in sector $\mathrm{s}$ in jaar $\mathrm{t}$

$Y_{s, t} \quad=$ aantal leerovereenkomsten in verhouding tot het arbeidsvolume in sector $s$ en jaar $\mathrm{t}$

$F(.,) \quad=$. functie van verklarende variabelen en parameters

$X_{s, t} \quad=$ matrix van verklarende variabelen voor sector $\mathrm{s}$

$\theta_{s} \quad=$ vector van parameters voor sector $s$ 
Verondersteld wordt dat de vraagfactoren een optimale waarde van de endogene variabele bepalen, maar dat in éen periode slechts een bepaalde fractie $\pi$ van de gewenste aanpassing plaats vindt. Dit partiële aanpassingsmechanisme kan worden gezien als het gevolg van gewoontevorming ('habit formation') in het aanbod van praktijkplaatsen door bedrijven. Dit betekent dat niet alleen de actuele economische omstandigheden, maar ook de vraag naar leerlingen in het verleden van belang is. Zo is het bijvoorbeeld denkbaar dat het afbreken van opleidingscapaciteit, die in het verleden gecreëerd is, meer kosten met zich meebrengt dan het tijdelijk in stand houden van deze opleidingscapaciteit, ondanks de tijdelijk afgenomen vraag naar leerlingen. Dit proces van partiële aanpassing, kan als volgt worden gemodelleerd (Judge cs., 1980):

$Y_{t}^{*}=F\left(X_{t}, \theta\right)+v_{t}$

waarbij $v_{t}$ een storingsterm is.

In vergelijking (8) komt tot uitdrukking dat het optimale aandeel van leerovereenkomsten in het arbeidsvolume volledig wordt bepaald door determinanten van de vraag.

$Y_{t}-Y_{t-1}=\pi *\left(Y_{t}^{*}-Y_{t-1}\right)$

In (9) komt tot uitdrukking dat de feitelijk gerealiseerde verandering van het aantal leerovereenkomsten in verhouding tot het arbeidsvolume in een bepaald jaar slechts een gedeelte $(\pi)$ betreft van de in feite gewenste aanpassing.

Substitutie van (8) in (9) leidt tot een schattingsmodel met een vertraagde endogene variabele:

$Y_{t}=\pi * F\left(X_{t}, \theta\right)+(1-\pi) * Y_{t-1}+\pi * v_{t}$

\subsection{Econometrische modellering}

Doorgaans wordt een logaritmische transformatie gekozen ten einde negatieve waarden van het aandeel $Y_{t}$ en problemen van heteroscedasticiteit te vermijden. Op basis van een aantal schattingen en het criterium van Box en Cox is gebleken dat een logaritmische transformatie inderdaad de voorkeur verdient boven een lineair verband ${ }^{4}$. De vergelijking die per sector wordt

4. Box en Cox hebben een procedure ontwikkeld om op basis van de data een geschikte functionele vorm te kiezen. In deze procedure wordt allereerst de endogene variabele $Y_{t}$ getransformeerd tot een variabele $Y_{t}(\mu)=\left(Y_{t}^{\mu}-1\right) / \mu \dot{Y}^{\mu-1}$, waarbij $\dot{Y}=\left(\prod_{t}^{n} Y_{t}\right)^{1 / n}$. Vervolgens wordt deze getransformeerde endogene geregresseerd op de exogenen voor verschillende waarden van $\mu$. Uiteindelijk wordt voor $\mu$ een waarde gekozen die de residuele kwadratensom minimaliseert. Voor de schattingen in dit onderzoek zijn alleen de waarden $\mu=1$ (originele data) en $\mu=0$ (logaritmische transformatie) met elkaar vergeleken. 
geschat luidt aldus:

$$
\begin{aligned}
\log \left(Y_{s, t}\right)= & \theta_{1}+\theta_{2} * \log \left(Y_{s, t-1}\right)+\theta_{3} * \log \left(T E C H_{s, t}\right)+\theta_{4} * \log \left(B E Z_{s, t}\right)+ \\
& \theta_{5} * \log \left(B V J_{t}\right)+u_{s, t}
\end{aligned}
$$

met:

$Y_{s, t}=\frac{T_{s, t}}{W_{s, t}} \quad=\begin{aligned} & \text { aandeel van het totaal aantal leerovereenkomsten in het arbeidsvolume in } \\ & \text { sector } \mathrm{s} \text { in jaar } \mathrm{t}\end{aligned}$

$T_{s, t} \quad=$ totaal aantal leerovereenkomsten in sector $\mathrm{s}$ in jaar $\mathrm{t}$

$W_{s, t} \quad=$ arbeidsvolume in 1000 mensjaren in sector $\mathrm{s}$ in jaar $\mathrm{t}$

$\mathrm{TECH}_{s, t} \quad=$ kapitaal-arbeidsratio in sector $\mathrm{s}$ in jaar $\mathrm{t}$

$B E Z_{s, t} \quad=$ bezettingsgraad in bedrijven in sector $\mathrm{s}$ in jaar $\mathrm{t}$

$B V J_{t} \quad=$ omvang subsidie volgens de BVJ-regeling in jaar $\mathrm{t}$

$u_{s, t} \quad=$ storingsterm, standaard normaal verdeeld, uitgezonderd in de sectoren waarin eerste orde autocorrelatie is geconstateerd.

$\mathrm{Er}$ is ook onderzocht of er sprake is van eerste orde autocorrelatie. Vanwege het feit dat een vertraagde endogene in de vergelijking is opgenomen, kan de Durbin en Watson toets niet gebruikt worden. Er is daarom een alternatieve procedure gevolgd om eventueel het optreden van eerste orde autocorrelatie te achterhalen ${ }^{5}$. Voor een aantal sectoren is geconstateerd dat er sprake is van eerste orde autocorrelatie. In de schattingsvergelijking voor deze sectoren is derhalve een parameter voor eerste orde autocorrelatie opgenomen.

5. De meest geëigende methode om eerste orde autocorrelatie te berekeken voor een vergelijking met een vertraagde endogene is het berekenen van Durbin's $h$. Deze grootheid kan echter niet in alle gevallen worden berekend. Er is daarom gekozen voor een procedure die asympotisch identiek is. De methode (Judge cs., 1988) bestaat hieruit dat de residuen van de vergelijking worden geregresseerd op de vertraagde residuen en de overige verkarende variabelen (inclusief de vertraagde endogene). Indien de parameter van de vertraagde residuen significant van nul verschilt, behoort een term voor eerste orde autocorrelatie in de oorspronkelijke vergelijking te worden opgenomen. 


\section{SCHATTINGSRESULTATEN}

\subsection{Inleiding}

In dit hoofdstuk worden de resultaten van de schatting van vergelijking (11) besproken. Eerst worden in paragraaf 3.1. de resultaten voor de primaire leerovereenkomsten behandeld. Daarnaast wordt in paragraaf 3.2. ingegaan op de resultaten voor de voortgezette leerovereenkomsten. Vervolgens wordt in paragraaf 3.3. voor iedere sector afzonderlijk nagegaan in hoeverre de uitkomsten voor de primaire en voortgezette leerovereenkomsten van elkaar afwijken.

$\mathrm{Er}$ is bij de analyses nagegaan of er sprake is van ernstige multicollineairiteit tussen de verschillende determinanten van de vraag. Op basis van de conditiegetallen is geconstateerd dat er in een aantal sectoren sprake is van multicollineairiteit. Daarom is voor én sector, de metaalsector, door middel van 'ridge regression ${ }^{6 \prime}$ onderzocht of de schattingsresultaten sterk vertekend kunnen zijn vanwege multicollineairiteit tussen de variabelen. De geschatte parameters en de significantie van de parameters blijken echter volgens deze schattingstechniek weinig te verschillen van de hier gepresenteerde schattingen. Ook is geprobeerd de multicollineairiteitsproblematiek te ondervangen door na te gaan of lineaire transformaties van de vraagfactoren andere uitkomsten te zien gaven. Deze methode, die gezien kan worden als een vorm van principale componenten-analyse, gaf betere conditiegetallen en lagere correlaties. De schattingen weken desalniettemin eveneens weinig af van de hier gepresenteerde schattingen.

Op basis van deze resultaten kan worden geconcludeerd dat multicollineairiteit welliswaar een rol speelt, maar dat de parameterwaarden en de siginificantie van de parameters hierdoor niet sterk worden vertekend. Er zijn derhalve geen schattingstechnieken toegepast om te corrigeren voor multicollineairiteit.

\subsection{Primaire leerovereenkomsten}

De schattingsresultaten voor de primaire leeerovereenkomsten worden weergegeven in tabel 3.1. De vertraagde endogene variabele is bij het merendeel van de sectoren significant, waarbij de parameterwaarde per sector globaal varieert tussen de 0.5 en de 0.8 . De fractie $\pi$ varieert

6. 'Ridge regression' is een schattingstechniek die gebruikt kan worden als de matrix $X^{\prime} X$ singulier of bijna singulier is, hetgeen het geval is bij ernstige multicollineairiteit. Voor het berekenen van de parameters wordt niet bovengenoemde matrix geïnverteerd, maar de matrix $\left[X^{\prime} X+k * I_{n}\right]$. $k$ wordt op basis van een Bayesiaans criterium gekozen (Hall, 1987). 
derhalve van 0.2 tot 0.5 . Dit houdt in dat gewoontevorming in de vraag naar leerovereenkomsten een belangrijke rol speelt: per jaar vindt minder dan de helft van de gewenste aanpassing plaats.

Tabel 3.1. Schattingsresultaten primaire leerovereenkomsten

\begin{tabular}{|c|c|c|c|c|c|c|c|c|}
\hline \multirow[b]{2}{*}{ sector } & \multirow[b]{2}{*}{ Constante } & \multirow[b]{2}{*}{$Y(-1)$} & \multirow[b]{2}{*}{$\mathrm{TECH}$} & \multirow[b]{2}{*}{ BEZ } & \multirow[b]{2}{*}{ BVJ } & \multirow[b]{2}{*}{$\operatorname{adj} . R^{2}$} & \multirow[b]{2}{*}{ D.W. } & \multirow[b]{2}{*}{ rho } \\
\hline & & & & & & & & \\
\hline \multirow{2}{*}{ Metaal } & 1.17 & 0.800 & -0.098 & 0.995 & 0.021 & 0.756 & 1.65 & \\
\hline & (1.39) & $(6.56)$ & $(0.734)$ & $(1.47)$ & $(2.51)$ & & & \\
\hline \multirow[t]{2}{*}{ Bouw/hout } & 1.23 & 0.672 & -0.07 & 0.550 & 0.013 & 0.772 & 1.83 & 0.569 \\
\hline & $(0.46)$ & $(1.12)$ & $(0.25)$ & (0.53) & (0.77) & & & (0.78) \\
\hline \multirow[t]{2}{*}{ Consumptie } & 0.791 & 0.672 & 0.076 & 0.427 & 0.024 & 0.878 & 1.82 & \\
\hline & $(1.91)$ & $(4.51)$ & $(0.88)$ & $(1.17)$ & (3.01) & & & \\
\hline \multirow[t]{2}{*}{ Administratie } & -8.45 & 0.15 & 2.81 & 6.64 & 0.02 & 0.787 & 1.72 & \\
\hline & $(2.24)$ & $(0.65)$ & $(2.37)$ & $(2.00)$ & $(0.77)$ & & & \\
\hline \multirow[t]{2}{*}{ Grafisch } & 2.525 & 0.705 & -0.469 & 0.561 & 0.052 & 0.455 & 1.89 & 0.455 \\
\hline & $(1.03)$ & $(2.64)$ & $(0.92)$ & $(0.39)$ & $(1.67)$ & & & $(1.2)$ \\
\hline \multirow[t]{2}{*}{ Diensten } & 1.71 & 0.633 & -0.453 & -0.356 & 0.024 & 0.542 & 2.37 & \\
\hline & (2.12) & (3.37) & (1.63) & $(0.32)$ & $(2.44)$ & & & \\
\hline \multirow[t]{2}{*}{ VAPRO } & 0.095 & 0.695 & 0.105 & 0.188 & 0.044 & 0.788 & 1.89 & \\
\hline & $(0.05)$ & $(3.87)$ & $(0.29)$ & $(0.16)$ & $(1.79)$ & & & \\
\hline \multirow[t]{2}{*}{ Textiel } & 0.639 & 0.519 & 0.162 & 0.329 & 0.043 & 0.711 & 2.18 & \\
\hline & $(0.90)$ & $(2.77)$ & $(1.04)$ & $(0.28)$ & $(1.98)$ & & & \\
\hline \multirow[t]{2}{*}{ Transport } & -1.182 & 0.447 & 0.389 & -0.651 & 0.03 & 0.808 & 2.07 & \\
\hline & $(1.96)$ & $(2.42)$ & $(2.64)$ & $(0.29)$ & $(2.03)$ & & & \\
\hline \multirow[t]{2}{*}{ OVDB } & -0.864 & 0.358 & 0.878 & -0.110 & -0.003 & 0.493 & 2.02 & \\
\hline & $(0.41)$ & $(1.30)$ & (1.01) & $(0.08)$ & $(0.24)$ & & & \\
\hline
\end{tabular}

De parameter voor de technologie-variabele (kapitaal-arbeidratio) is significant in de transportsector en de adminstratieve sector. De parameters hebben een positief teken. Dit betekent dat naarmate er in deze bedrijfssectoren arbeid door kapitaal wordt vervangen er een relatief grotere vraag naar leerovereenkomsten ontstaat (in procenten van het arbeidsvolume). Hieruit kan worden geconcludeerd dat in die sectoren de technologische ontwikkelingen leiden tot een 
toename van de vraag naar geschoolde vakmensen.

De conjunctuur-variabele is alleen significant in de administratieve sector. Het teken van de parameter is in overeenstemming met de verwachtingen positief. Het is echter, gezien het beeld zoals dat in figuur 1 werd geschetst, opvallend dat deze variabele in de meeste sectoren niet significant is. De correlaties tussen deze variabele en de andere variabelen zijn erg laag, zodat multicollineairiteit uitgesloten is.

De BVJ beleidsvariabele is significant in diverse sectoren: metaal, consumptie, diensten, transport en textiel. Het teken van de parameter is positief, hetgeen in overeenstemming is met de verwachting dat een hogere vergoeding per praktijkplaats tot een stijging van het aantal leerovereenkomsten leidt. Wel moet daarbij worden opgemerkt dat de invloed van de BVJ beleidsvariabele beperkt is. Dit wordt duidelijk als men de waarden van de parameters als elasticiteiten opvat. Wanneer de subsidie met $1 \%$ zou stijgen, zou het aantal primaire leerovereenkomsten in de metaalsector met $0,02 \%$ stijgen en op lange termijn met nog slechts $0,02 / 0,20=0,11 \%$. Voor de andere sectoren waar deze variabele significant is varieert de lange termijn elasticiteit tussen 0,05 en $0,09 \%$.

De verklaarde variantie van de vergelijking is in de meeste sectoren circa 0.7. Dit houdt in dat de exogenen de variatie in de endogenen redelijk verklaren. Wel is deze hoge verklaarde variantie voor een belangrijk deel toe te schrijven aan de vertraagde endogene en - in sommige gevallen - de autoregressieve parameter voor eerste orde autocorrelatie, opgenomen in de vergelijkingen voor de bouw- en houtsector en de grafische sector.

\subsection{Voortgezette leerovereenkomsten}

De schattingsresultaten van de voortgezette leerovereenkomsten zijn weergegeven in tabel 3.2. De vertraagde endogene is bij het merendeel van de sectoren significant, waarbij de parameterwaarde varieert tussen de 0.34 en de 0.92 . De jaarlijkse partiële aanpassing varieert derhalve tussen de 0.08 en de 0.66 . Ook voor de meeste voortgezette leerovereenkomsten is er dus sprake van geleidelijke aanpassing. Voor twee sectoren, de administratieve en de dienstensector, zijn de coëfficiënten voor de vertraagde endogenen echter niet significant, zodat geconcludeerd kan worden dat de vraag in deze sectoren niet via partiële aanpassingen, maar direct reageert op economische ontwikkelingen.

De technologie-variabele is significant in de metaal-, de consumptieve, de diensten- en de administratieve sector. De desbetreffende parameters hebben, op die voor de dienstensector na, een positief teken. De interpretatie hiervan is analoog aan de interpretatie bij de primaire leerovereenkomsten: een toenemende intensivering van de techniek vereist in deze gevallen meer geschoolde vakmensen. 
Tabel 3.2. Schattingsresultaten voortgezette leerovereenkomsten

\begin{tabular}{|c|c|c|c|c|c|c|c|c|}
\hline \multicolumn{2}{|c|}{ variabele } & \multirow[b]{2}{*}{$Y(-1)$} & \multirow[b]{2}{*}{ TECH } & \multirow[b]{2}{*}{ BEZ } & \multirow[b]{2}{*}{ BVJ } & \multirow[b]{2}{*}{ adj. $R^{2}$} & \multirow[b]{2}{*}{ D.W. } & \multirow[b]{2}{*}{ rho } \\
\hline Sector & Constante & & & & & & & \\
\hline \multirow[t]{2}{*}{ Metaal } & -2.800 & 0.458 & 1.109 & -3.32 & 0.077 & 0.889 & 2.04 & \\
\hline & $(1.70)$ & $(2.41)$ & $(2.02)$ & (2.59) & $(0.49)$ & & & \\
\hline \multirow[t]{2}{*}{ Bouw/hout } & -0.02 & 0.918 & 0.067 & -0.22 & 0.006 & 0.741 & 1.38 & \\
\hline & $(0.03)$ & $(5.36)$ & $(0.44)$ & $(0.21)$ & $(0.39)$ & & & \\
\hline \multirow[t]{2}{*}{ Consumptie } & -1.185 & 0.459 & 0.623 & 1.353 & -0.004 & 0.89 & 2.34 & \\
\hline & $(2.58)$ & $(3.00)$ & $(3.61)$ & $(2.52)$ & $(0.035)$ & & & \\
\hline \multirow[t]{2}{*}{ Administratie } & -27.22 & -0.233 & 8.17 & 8.26 & 0.03 & 0.881 & 1.33 & \\
\hline & (3.73) & $(0.86)$ & $(3.74)$ & $(2.02)$ & $(1.02)$ & & & \\
\hline \multirow[t]{2}{*}{ Grafisch } & -6.03 & 0.618 & 1.70 & 2.37 & -0.006 & 0.59 & 2.01 & 0.304 \\
\hline & $(1.82)$ & $(2.1)$ & $(1.2)$ & $(1.6)$ & $(0.2)$ & & & $(0.59)$ \\
\hline \multirow[t]{2}{*}{ Diensten } & -0.717 & -0.09 & -0.958 & -1.15 & -0.02 & 0.115 & 2.27 & \\
\hline & $(0.85)$ & $(0.39)$ & $(2.08)$ & $(0.78)$ & $(1.4)$ & & & \\
\hline \multirow[t]{2}{*}{ VAPRO } & -13.47 & 0.745 & 2.48 & 1.60 & 0.12 & 0.279 & 2.07 & \\
\hline & $(0.90)$ & $(3.16)$ & $(0.89)$ & $(0.30)$ & $(1.67)$ & & & \\
\hline \multirow[t]{2}{*}{ Textiel } & -0.253 & 0.523 & -0.07 & -3.56 & 0.07 & 0.24 & 2.08 & \\
\hline & $(0.14)$ & $(1.32)$ & $(0.128)$ & $(0.76)$ & $(0.94)$ & & & \\
\hline \multirow[t]{2}{*}{ Transport } & 0.851 & 0.75 & -0.276 & 0.883 & 0.046 & 0.561 & 2.10 & \\
\hline & $(0.87)$ & $(3.31)$ & $(1.08)$ & $(0.25)$ & (2.19) & & & \\
\hline \multirow[t]{2}{*}{ OVDB } & -5.358 & 0.339 & 2.200 & -9.79 & 0.07 & 0.911 & 2.74 & \\
\hline & 0.411 & $(1.30)$ & $(0.78)$ & $(2.33)$ & $(1.37)$ & & & \\
\hline
\end{tabular}

De conjunctuur-variabele is significant in de metaal-, de consumptieve, de adminstratieve en de verzorgende sector. De tekens van de parameters zijn echter zowel negatief als positief. Verschillende tekens voor deze variabele wijzen op de mogelijkheid dat tegengesteld gereageerd wordt op de conjunctuur. Een positieve coëfficient wijst op het verwachte positieve verband tussen de bedrijvigheid en het aantal afgesloten leerovereenkomsten. Het niet verwachte negatieve teken voor de coëfficient van de conjunctuur-variabele voor de metaal- en de verzorgende sector zou kunnen wijzen op het verschijnsel dat leerlingen met een leerovereenkomst in een periode van hoogconjunctuur eerder hun opleiding voortijdig beëindigen, vanwege de zuigkracht van de arbeidsmarkt. 
De BVJ beleidsvariabele is bij de voortgezette leerovereenkomsten alleen significant in de transportsector. Het teken van de parameter is positief, hetgeen in overeenstemming is met de verwachting dat een hogere vergoeding per praktijkplaats (lagere loonkosten) tot een stijging van het aantal leerovereenkomsten leidt. Ook hier gaat het echter om een gering kwantitatief effect.

De verklaarde variantie van de vergelijkingen verschilt aanzienlijk. Deze is hoog voor de verzorgende sector, de metaalsector, de consumptieve en de administratieve sector en zeer laag voor de dienstensector, de textielsector en de VAPRO sector. Voor de grafische sector is gecorrigeerd voor eerste orde autocorrelatie.

\subsection{Bespreking van de resultaten per sector}

In de metaalsector hebben de conjunctuur- en de technologievariabele meer verklaringskracht bij de voortgezette leerovereenkomsten dan bij de primaire leerovereenkomsten. Hetzelfde geldt voor de consumptieve sector en de verzorgende sector. Bij de overige sectoren is het beeld voor de primaire en voortgezette leerovereenkomsten vrijwel identiek. Beide variabelen bieden met name een goede verklaring voor het aantal leerovereenkomsten in de administratieve sector. In deze sector lijken bovendien partiële aanpassingsprocessen geen rol te spelen, aangezien de parameter voor de vertraagde endogene niet significant is. Voor deze sector zijn de tekens van de parameters van de conjunctuur- en de technologievariabele in de vergelijking voor de primaire en voortgezette leerovereenkomsten hetzelfde. Opvallend is dat de BVJ-variabele veel vaker significant is bij de primaire leerovereenkomsten, maar niet bij de voortgezette leerovereenkomsten. Dit hangt waarschijnlijk samen met het feit dat deze subsidieregeling met name bedoeld is voor primaire leerovereenkomsten. 


\section{CONCLUSIES}

In deze studie is onderzocht in hoeverre economische determinanten (vraagfactoren) bepalend zijn voor het aantal leerovereenkomsten. In een eerdere studie is onderzocht in hoeverre aanbodfactoren (het aanbod van leerlingen) een rol spelen bij de ontwikkeling van het aantal leerovereenkomsten.

De uitsplitsing van het aantal leerovereenkomsten die in Lodder, De Grip en Heijke (1992) is gemaakt in gecontinueerde, nieuwe en beëindigde leerovereenkomsten, blijkt ook vruchtbaar te zijn om een onderscheid tussen uitbreidings- en vervangingsvraag te kunnen maken. De verandering van het totale aantal leerovereenkomsten is gelijk te stellen aan de uitbreidingsvraag naar leerovereenkomsten. Economische variabelen die de uitbreidingsvraag verklaren kunnen dan gezien worden als een verklaringsgrond voor het totale aantal leerovereenkomsten.

Het beroepenmodel van Dekker, De Grip en Heijke (1992) biedt aanknopingspunten om de determinanten van de vraag te bepalen. In het ontwikkelde model in deze studie is de betekenis van een viertal verklaringsgronden nagegaan. In de eerste plaats is een kapitaal-arbeidsratio gebruikt als indicator voor de technologische ontwikkeling. In de tweede plaats is een proxyvariabele voor de sectoriële bezettingsgraad gebruikt als indicator voor conjuncturele fluctuaties. In de derde plaats is met structurele sector-specifieke factoren rekening gehouden door het aantal leerovereenkomsten te schalen met het arbeidsvolume in de desbetreffende sector. Tenslotte is een kostenvariabele (BVJ-subsidiebedrag per praktijkplaats) gebruikt als indicator voor de prijs van arbeid.

Bij de specificatie van het model is rekening gehouden met de mogelijkheid dat er sprake is van een proces van partiële aanpassing. Dit houdt in dat de exogene variabelen weliswaar een optimale waarde van de endogene bepalen, maar dat in een bepaald jaar slechts een gedeelte van de aanpassing wordt gerealiseerd. Een dergelijke proces kan gemodelleerd worden door een vertraagde endogene variabele toe te voegen. Daarnaast is geconstateerd dat er in een in aantal sectoren sprake is van eerste orde autocorrelatie. Voor deze sectoren is een parameter voor eerste orde autorcorrelatie toegevoegd.

Bij het schatten van het model is het vermoeden ontstaan dat er sprake is van multicollineairiteit. Door middel van daarvoor geëigende procedures is onderzocht of deze multicollineairiteit de onderzoeksresultaten ernstig verstoort. Dit blijkt niet het geval te zijn.

De variabele die als indicator voor het optreden van conjuncturele factoren in het model is opgenomen blijkt slechts in een aantal sectoren significant te zijn. Dit strookt niet met de algemene gedachte dat de markt voor leerovereenkomsten conjunctuurgevoelig is. Bij vervolg- 
onderzoek zou een andere modellering mogelijk tot meer inzicht in deze kwestie kunnen leiden. De variabele die als indicator voor de technologische ontwikkeling is gebruikt, heeft eveneens in slechts een gering aantal sectoren een significante invloed. De BVJ-beleidsvariabele is daarentegen significant in een groot aantal sectoren in het primaire leerlingwezen en heeft in die gevallen het verwachte positieve teken. Desalniettemin is de kwantitatieve betekenis van de subsidieregeling relatief gering. De vertraagde endogene is in vrijwel iedere sector significant. Dit impliceert dat geleidelijke aanpassingsprocessen c.q. gewoontevorming ('habit formation') doorgaans een zeer belangrijke rol spelen.

De conclusie met betrekking tot het model met vraagfactoren is dat voor de meeste sectoren gewoontevorming bij bedrijven een belangrijke rol speelt in de vraag naar leerovereenkomsten. Andere factoren, zoals de bezettingsgraad in bedrijven en de kapitaal-arbeidsratio spelen in mindere mate een rol. De vergoedingen die plaatsvinden in het kader van de BVJ-regeling blijken met name de vraag naar primaire leerovereenkomsten te beïnvloeden. Bij de administratieve sector is geconstateerd dat er sprake is van conjunctuurgevoeligheid. Ook stijgt in deze sector de vraag naar leerovereenkomsten bij een stijging van de kapitaal-arbeidsratio. In deze sector speelt gewoontevorming echter geen rol.

Bij de interpretatie van deze schattingsresultaten moet worden bedacht dat er getracht is een verklaring te vinden voor het aandeel dat de leerovereenkomsten uitmaken van het arbeidsvolume. Hoewel de gevonden resultaten beperkt zijn, betekent dit niet dat economische factoren geen enkele rol spelen bij het afsluiten van leerovereenkomsten. Voorzover het aantal leerovereenkomsten varieert met het arbeidsvolume zijn de variabelen die de totale arbeidsvraag c.q. gerealiseerde werkgelegenheid bepalen ook van invloed op het aantal leerovereenkomsten. Er kan evenwel geconstateerd worden dat de onderzochte economische determinanten nauwelijks (extra) invloed uitoefenen op de mate waarin de vraag naar arbeid wordt gerealiseerd in de vorm van leerlingplaatsen.

Met betrekking tot de in de inleiding genoemde mogelijkheid van het schatten van een model waarin zowel aanbod- als vraagfactoren zijn opgenomen, moet worden geconstateerd dat het niet zinvol lijkt om variabelen als de bezettingsgraad (conjunctuur-indicator) en de kapitaalarbeidsratio als vraagfactoren op te nemen in een vergelijking waarin de leerovereenkomsten zijn uitgedrukt als aandeel van het sectorale arbeidsvolume. In de meeste sectoren hebben deze variabelen immers geen significante invloed op de ontwikkeling van het aantal leerovereenkomsten als percentage van het arbeidsvolume. Bovendien kleven er aan het schatten van dergelijke modellen een groot aantal bezwaren die hun praktische bruikbaarheid waarschijnlijk sterk zal beperken. 


\section{LITERATUUR}

Centraal Planbureau (1990), Centraal Economisch Plan, Den Haag.

Dekker, R.J.P., A. de Grip, J.A.M. Heijke (1990), An Explanation of the Occupational structure of Sectors of Industries in: Labour, vol.4, nr. 3, winter 1990, pp. 3-31.

Directoraat Generaal voor de Arbeidsvoorziening (1990), Voortgangsrapportage BVJ 1989/1990, Den Haag.

Frietman , J., B.W.M. Hövels (1990), Leerlingwezen als opleidingsweg in en van het bedrijfsleven, in: Jeugd en samenleving, oktober $1990-10$.

Galan, C., de (1981), Economie van de arbeid, Samsom, Alphen aan den Rijn.

Grip, A., de, J.A.M. Heijke, R.J.P. Dekker (1989), De arbeidsmarkt naar opleiding en beroep in 1992, ROA-R-1989/8, Maastricht.

Hall, B.H., Schnake, R., Cummins, C. (1987), TSP User's Manual, TSP International, Palo Alto.

Hövels, B.W.M. (1985), Arbeidsorganisaties en het leerlingwezen, een onderzoek naar het aanbod van leer-arbeidsplaatsen door arbeidsorganisaties, Ministerie van Sociale Zaken en Werkgelegenheid, Den Haag.

Judge, G.G., W.E. Griffiths, R. Carter Hill, T.C. Lee (1980), The theory and practice of econometrics, Wiley \& Sons, Toronto.

Kooiman, P., T. Kloek (1979), Aggregation of micro markets in disequilibrium, theory and application to the Dutch Labour Market 1948-1975, Erasmus Universiteit, Rotterdam.

Lodder, B.J.H., A. de Grip, J.A.M. Heijke (1992), In- en uitstroom op de markt voor leerovereenkomsten, ROA-RM-1992/1, Maastricht.

Maddala, G.S. (1983), Limited-dependent and qualitative variables in econometrics, Cambridge, University Press, Cambridge.

Ministerie van Sociale Zaken en Werkgelegenheid (1990), Brief van de minister van Sociale Zaken aan de Tweede Kamer, vergaderjaar 1989-1990, 21 314, nrs 1-2.

Ministerie van Sociale Zaken en Werkgelegenheid (1985), Educatie in CAO's, Den Haag.

Oosterbeek, H., C.N. Teulings, H.D. Webbink (1991), Het voorspellen van de vraag naar hoger onderwijs, in: J.K. Koppen, H. Stroomberg, M. van der Kamp, Hoger onderwijs en volwasseneneducatie; Onderwijsresearchdagen '91, SCO, Amsterdam.

Peeters, H.M.M. (1990), An explanation of the occupational and educational structure of employment by means of multinomial logit, ROA-W-1990/4E, Maastricht.

SAS/ETS (1988), User's Guide, Versie 6, 1e editie, SAS Institute Inc, Cary, NC. 


\section{DE INVLOED VAN VRAAGFACTOREN OP DE MARKT VOOR LEEROVEREENKOMSTEN}

\section{ROA-RM-1992/3}

A. de Grip, J.A.M. Heijke, B.J.H. Lodder

\section{RESEARCHCENTRUM VOOR ONDERWIJS EN ARBEIDSMARKT}

Faculteit der Economische Wetenschappen

Rijksuniversiteit Limburg

Maastricht, mei 1992 
CIP-GEGEVENS KONINKLIJKE BIBLIOTHEEK, DEN HAAG

Grip, A. de

De invloed van vraagfactoren op de markt voor leerovereenkomsten / A. de Grip, J.A.M. Heijke, B.J.H. Lodder. - Maastricht: Researchcentrum voor Onderwijs en Arbeidsmarkt, Faculteit der Economische Wetenschappen, Rijksuniversiteit Limburg. - (Research memorandum / Researchcentrum voor Onderwijs en Arbeidsmarkt ; 1992/3)

Met lit. opg.

ISBN 90-5321-083-0 in spiraalband

Trefw.: leerlingwezen. 
INHOUDSOPGAVE

bladzijde

SAMENVATTING

1. INLEIDING

1

2. DE VRAAG NAAR LEEROVEREENKOMSTEN

2.1. Inleiding

4

2.2. Determinanten van de vraag

2.3. Econometrische modellering $\quad 8$

3. SCHATTINGSRESULTATEN 10

3.1. Inleiding 10

3.2. Primaire leerovereenkomsten 10

3.3. Voortgezette leerovereenkomsten 12

$\begin{array}{ll}\text { 3.4. Bespreking van de resultaten per sector } & 14\end{array}$

4. CONCLUSIES 15

$\begin{array}{ll}\text { LITERATUUR } & 17\end{array}$ 


\section{SAMENVATTING}

Op de markt voor leerovereenkomsten in het leerlingwezen spelen zowel vraag- als aanbodfactoren een rol. In deze studie is onderzocht in hoeverre de ontwikkeling van het aantal leerovereenkomsten te verklaren is met behulp van louter vraagfactoren. Uit de resultaten blijkt dat gewoontevorming bij bedrijven een belangrijke rol speelt in de vraag naar leerovereenkomsten. Uit de schattingsresultaten blijkt niet dat andere factoren, zoals de bezettingsgraad in bedrijven en de kapitaal-arbeidsratio een belangrijke rol spelen. Hoewel de vergoedingen die in het kader van de Bijdrageregeling Vakopleiding Jeugdigen (BVJ) plaatsvinden een significante invloed uitoefenen op de vraag naar leerovereenkomsten, blijkt uit de vraagelasticiteit met betrekking tot de genoemde regeling dat het om een relatief gering kwantitatief effect gaat. 


\section{INLEIDING}

De deelname aan een specifieke vorm van vervolgonderwijs wordt in de regel voorspeld door de omvang van de uitstroom uit de verschillende vooropleidingen te relateren aan een geschat instroompercentage. Zo wordt bijvoorbeeld bij de volumeraming van het aantal eerstejaars studenten door de Taakgroep Studentenraming (1990) de uitstroom uit het VWO vermenigvuldigd met het percentage leerlingen van het VWO dat in het voorafgaande jaar is gaan studeren. Hoewel deze procedure geen foutloze voorspellingen oplevert, concluderen Oosterbeek, Teulings en Webbink (1991) dat een dergelijke prognosetechniek goed stand houdt in vergelijking met prognoses op basis van causale modellen.

Voor de voorspelling van de ontwikkeling van het aantal leerovereenkomsten is deze procedure echter enigszins onbevredigend, omdat geen rekening wordt gehouden met de economische ontwikkelingen die van invloed kunnen zijn op het aantal leerovereenkomsten. Zo is er in het verleden sprake geweest van een tekort aan praktijkplaatsen als gevolg van economische recessies. Uit figuur 1 blijkt dat het aantal primaire en voortgezette leerovereenkomsten een aanzienlijke daling te zien geeft in de recessieperioden rond de jaren 1975 en 1982.

Voor het tot stand komen van een leerovereenkomst is het nodig dat een bedrijf een praktijkplaats aanbiedt en dat een leerling die praktijkplaats wenst te bezetten. In overeenstemming met deze gedachtengang zou men kunnen spreken over het aanbod van praktijkplaatsen door bedrijven en de vraag naar praktijkplaatsen door leerlingen. In deze studie is er echter voor gekozen om aansluiting te zoeken bij de terminologie van de economische arbeidsmarkttheorie. Daarbij wordt met het aanbod van arbeid het aanbod van werknemers bedoeld. De vraag heeft dan betrekking op de vraag naar werknemers door werkgevers. Analoog hieraan wordt gesproken van de vraag naar leerlingen door bedrijven (het aanbod van prakijkplaatsen) en het aanbod van leerlingen (de vraag naar prakijkplaatsen door leerlingen).

In beginsel zou bij de specificatie van een model, waarin een causale verklaring wordt gegeven van de ontwikkeling van het aantal leerovereenkomsten, rekening moeten worden gehouden met zowel vraag- als aanbodfactoren. Problematisch daarbij is dat zowel de vraag als het aanbod niet worden waargenomen ${ }^{1}$, maar alleen het feitelijk aantal leerovereenkomsten.

1. De CBS-gegevens van het totaal aantal leerlingen in het leerlingwezen (inclusief degenen zonder leerovereenkomst) zouden in beginsel kunnen worden opgevat als het aanbod. Deze gegevens sluiten echter niet goed aan bij de CBS-gegevens van het aantal afgesloten leerovereenkomsten. Voor een aantal waarnemingsjaren blijkt het aantal afgesloten leerovereenkomsten zelfs groter te zijn dan het totaal aantal leerlingen in het leerlingwezen en deeltijd-KMBO. 


\section{$\times 1000$}

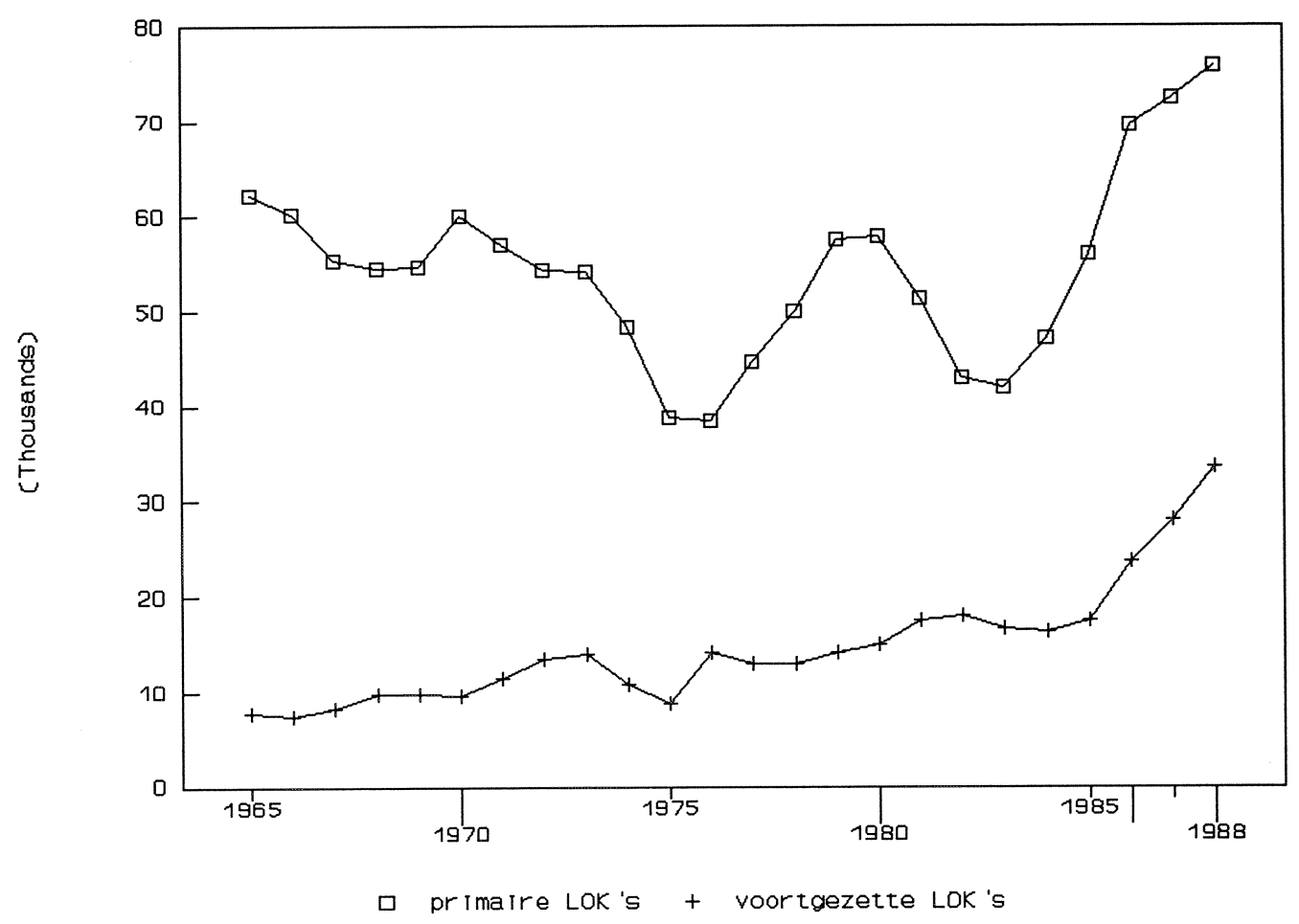

Bron: CBS/ROA

Hoewel het in principe mogelijk is een dergelijk model te schatten, wordt in de literatuur gewezen op een aantal problemen die de praktische relevantie van de methode beperkt (Maddala, 1983; Kooiman en Kloek, 1979).

Derhalve is er door ons voor gekozen om het onderzoek naar de ontwikkeling van het aantal leerovereenkomsten in enkele stappen te faseren. In een eerdere studie is met zogenaamde 'fractiemodellen' het aantal leerovereenkomsten verklaard uit de ontwikkeling van het aantal leerlingen. (Lodder, De Grip, Heijke, 1992). De verandering van totaal aantal leerovereenkomsten werd daarbij allereerst uitgesplitst in een in- en uitstroom van leerlingen. De instroom werd vervolgens verklaard op basis van de uitstroom uit het LTO/ITO, LHNO/IHNO en de MAVO. De uitstroom werd tenslotte verklaard op basis van het aantal in de voorgaande jaren ingestroomde leerlingen. De fracties werden op basis van tijdreeksen geschat. Bij deze 
benadering staat dus het aanbod van leerlingen centraal.

In aanvulling op bovengenoemde studie wordt in deze studie onderzocht in hoeverre vraagfactoren van invloed zijn op het aantal afgesloten leerovereenkomsten. Daarbij wordt gekeken naar de invloed van het subsidiebeleid van de overheid (Bijdrageregeling Vakopleiding Jongeren, BVJ), conjuncturele fluctuaties, de technologische ontwikkeling en andere structurele factoren. Zoals gezegd, is het in principe mogelijk een model met zowel aanbod- als vraagfactoren te schatten. Hierop zal in het laatste hoofdstuk worden teruggekomen.

In de hier gepresenteerde analyse zal dus volledig worden afgezien van de invloed van aanbodfactoren bij de verklaring van het aantal leerovereenkomsten. In beginsel hoeft dit niet onrealistisch te zijn. Als het aantal leerovereenkomsten over een groot deel van de waarnemingsperiode vraaggeïnduceerd is, dan zijn het met name vraagfactoren (economische variabelen) die het aantal leerovereenkomsten verklaren. In tijden van laagconjunctuur werd een tekort aan praktijkplaatsen geconstateerd, zodat in die periode het aantal leerovereenkomsten duidelijk vraaggeïnduceerd is geweest. Voor de overige jaren in de waarnemingsperiode (19681988) blijft de veronderstelling realistisch voorzover de vraag naar leerlingen het aanbod niet heeft overtroffen. Frietman en Hövels (1990) wijzen er evenwel op dat op de markt voor leerovereenkomsten recentelijk een omslag heeft plaatsgevonden: "Die omslag betreft de verhouding tussen aanbod en vraag naar praktijkplaatsen. De aantrekkende economie, demografische ontwikkelingen en ook de getalsmatige aderlating die met name het LBO ondergaat, hebben een tekort aan prakijkopleidingsplaatsen langzamerhand doen omslaan in een tekort aan leerlingen". Dit impliceert dat verwacht mag worden dat het schatten van een model met louter vraagfactoren op een dataset met waarnemingen uit de periode 1965-1989, dus voor de genoemde omslag, redelijk goede resultaten oplevert, maar waarschijnlijk minder adequaat is voor het prognosticeren van de ontwikkelingen in de eerste helft van de jaren ' 90 .

De verdere opbouw van deze studie is als volgt. In hoofdstuk 2 wordt het ontwikkelde model geformuleerd. Allereerst wordt in dit hoofdstuk het vraagbegrip nader uitgewerkt. Vervolgens worden de determinanten van de vraag besproken, waarna wordt ingegaan op de econometrische modellering. In hoofdstuk 3 worden de schattingsresultaten besproken, waarbij achtereenvolgens wordt ingegaan op de primaire en de voortgezette leeroverkomsten. In hoofdstuk 4 wordt een aantal conclusies getrokken. 


\section{DE VRAAG NAAR LEEROVEREENKOMSTEN}

\subsection{Inleiding}

De invloed van de economische ontwikkeling op het aantal leerovereenkomsten kan het beste worden geanalyseerd op het niveau van bedrijfssectoren, waaraan de opleidingssectoren binnen het leerlingwezen in meer of mindere mate nauw zijn gerelateerd. Daarom zijn de aantallen leeroverkomsten die zijn afgesloten binnen de 28 landelijke opleidingsorganen geaggregeerd tot 10 (opleidings-)sectoren, zoals die door het CPB (1990) worden onderscheiden. Deze opleidingsen bedrijfssectoren worden in tabel 2.1 weergegeven.

Tabel 2.1. Overzicht van opleidingssectoren in relatie tot bedrijfssectoren

Opleidingssectoren Bedrijfssectoren

Metaalverwerkende en

electronische sector

Bouw- en houtsector

Consumptieve sector

Administratieve sector

Grafische sector

Transportsector

Procesindustrie (VAPRO)

Textiel- en kledingsector

Dienstverlenende sector

Verzorgende sector (OVDB)
Basismetaalindustrie (BS)

Metaalprodukten- en optische industrie (MO)

Elektronische industrie (EL)

Hout- en bouwmaterialenindustrie (HB)

Bouwnijverheid (BO)

Voedingsmiddelenindustrie

Handel (HA)

Bank- en verzekeringswezen (BV)

Papier-en grafische industrie (PG)

Zee- en luchtvaart (ZL)

Overig transport (OT)

Chemische- en rubberindustrie (CR)

Textiel-, kleding-, leder-, en schoenindustrie (TK)

Andere tertiaire diensten (AD)

Medische en veteraine diensten (MD)

Voor een juiste modelspecificatie, is het nodig een goed beeld te hebben van de te verklaren variabele: het aantal leerovereenkomsten. Veronderstel dat er $T_{s, t-1}$ leerovereenkomsten zijn in sector $S$ in het jaar $t-1$. Het aantal leerovereenkomsten in sector $S$ in het jaar $t$ is dan per definitie gelijk aan $T_{s, t-1}$, vermeerderd met het aantal nieuw afgesloten leerovereenkomsten in dat jaar, $N_{s, t}$, en verminderd met het aantal beëindigde leerovereenkomsten, $E_{s, t}$. Het aantal beëindigde leerovereenkomsten kan daarbij worden opgesplitst in voortijdig beëindigde leerovereenkomsten, $P_{s, t}$ en leerovereenkomsten die beëindigd zijn vanwege het behalen van een certificaat of diploma, $C_{s, t}$ In formulevorm kan dit worden genoteerd als:

$T_{s, t}=T_{s, t-1}+N_{s, t}-E_{s, t}$ 
$E_{s, t}=C_{s, t}+P_{s, t}$

Op basis hiervan wordt de verandering van het aantal leerovereenkomsten gedefinieerd als:

$D_{s, t}=T_{s, t}-T_{s, t-1}$

Op voorhand is niet duidelijk of economische variabelen gezien moeten worden als verklarende variabelen voor het totaal, $\mathrm{T}_{\mathrm{s}, \mathrm{t}}$ het aantal nieuwe, $\mathrm{N}_{\mathrm{s}, t}$ of de verandering van het aantal leerovereenkomsten, $D_{s, t}$. Daarvoor is allereerst een nadere beschouwing van het begrip vraag noodzakelijk.

De totale vraag naar leerovereenkomsten, kan worden uitgesplitst in de uitbreidings- en vervangingsvraag. De som van de uitbreidings- en vervangingsvraag is gelijk aan het aantal 'jobopenings (De Grip, Heijke en Dekker, 1989). Analoog daaraan zou men met betrekking tot de leerovereenkomsten kunnen spreken van 'LOK-openings'. Het aantal nieuwe leerovereenkomsten, $\mathrm{N}_{\mathrm{s}, t}$ is zodoende gelijk aan de som van de uitbreidings- en vervangingsvraag. De vervangingsvraag is dan gelijk aan het aantal leerlingen dat een leerovereenkomst beëindigt en de uitbreidingsvraag is gelijk aan de verandering van het aantal leerovereenkomsten:

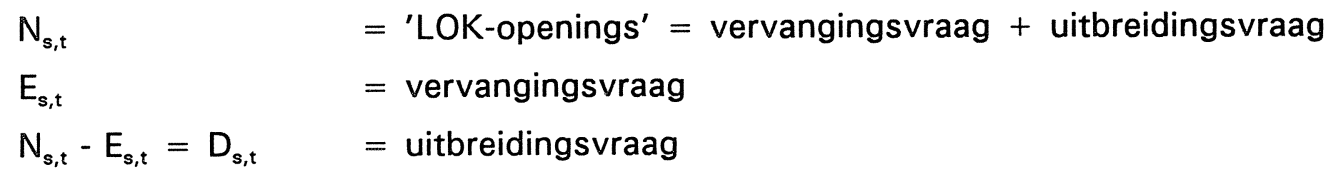

Economische variabelen worden in arbeidsmarktmodellen doorgaans gerelateerd aan de uitbreidingsvraag of de verandering van de werkgelegenheid (De Galan, 1981). Analoog hieraan kunnen in het te ontwikkelen model van leerovereenkomsten de economische variabelen worden gerelateerd aan het totaal aantal leerovereenkomsten, $T_{s, t}$. of de verandering van het aantal leerovereenkomsten $D_{s, t}$.

\subsection{Determinanten van de vraag}

Hövels (1985) heeft een onderzoek verricht naar het 'aanbod van leerarbeidsplaatsen' door bedrijven. De resultaten van deze studie zijn echter niet direct bruikbaar voor het formuleren van een vraagmodel op sectorniveau. De studie van Dekker, De Grip en Heijke (1990) biedt wel aanknopingspunten voor de formulering van het model. Aangezien een leerovereenkomst een specifiek type arbeidscontract betreft, is een vergelijking met de aandelen van beroepsklassen in het beroepenmodel van Dekker c.s. gerechtvaardigd, temeer daar in de laatstgenoemde studie eveneens wordt verondersteld dat de beroepenstructuur van de werkgelegenheid vraaggeïnduceerd is, hetgeen ook hier het uitgangspunt is. Dekker c.s. onderscheiden de volgende vier factoren die van invloed kunnen zijn op de (beroepen) structuur van de 
werkgelegenheid:

- de ontwikkeling van de loonkosten;

- de technologische ontwikkeling;

- overige bedrijfstak gebonden structurele factoren;

- bedrijfstak gebonden conjuncturele factoren.

De eerste factor, de ontwikkeling van de loonkosten, wordt door Dekker c.s. niet verder in beschouwing genomen. Verondersteld wordt dat de invloed van de loonstructuur constant is. Daarbij wordt gewezen op complicaties bij de modellering vanwege het feit dat het loon zowel een vraag- als aanbodfactor is. In deze studie wordt overigens wel een variabele gespecificeerd die mede bepalend is voor de prijs van arbeid, namelijk de omvang van de subsidie die in het kader van de Bijdrageregeling Vakopleiding Jeugdigen wordt gegeven aan bedrijven (de BVJsubsidie). Deze subsidieregeling is van kracht sinds 1983. Het betreft een bedrag per praktijkplaats. De hoogte van de subsidie hangt niet af van het aanbod van leerlingen, en kan derhalve als exogene variabele in het model worden opgenomen ${ }^{2}$.

Voor de specificering van de variabele die de invloed van de technologische ontwikkeling op het aantal leerovereenkomsten weergeeft, is enigszins afgeweken van de door Dekker c.s. gebruikte variabele, door het structurele effect van de investeringen niet te relateren aan de toegevoegde waarde, maar aan het arbeidsvolume, gecorrigeerd voor conjunctuurschommelingen. Deze variabele vormt zodoende een benadering van de kapitaal-arbeidsratio van het produktieproces in een bedrijfssector en kan derhalve worden beschouwd als een indicator van de technologische ontwikkeling. De variabele is als volgt gedefinieerd ${ }^{3}$ :

2. De BVJ-variabele is als volgt geconstrueerd. Het totale bedrag dat beschikbaar is voor de subsidieregeling is gedeeld door het streefcijfer met betrekking tot het aantal leerlingen. Dit quotiënt is beschouwd als een redelijke benadering van het bedrag dat per praktijkplaats beschikbaar is. Vanaf 1983 heeft de variabele een waarde van rond de $f 4.500,-$. Aangezien de regeling pas vanaf de 1983 van kracht is, is de (logaritmisch getransformeerde) variabele voor de periode 1965-1982 op nul gesteld.

3. De cijfers over de ontwikkeling van de investeringen, het arbeidsvolume en de toegevoegde waarde zijn afkomstig van het $\mathrm{CPB}(1990)$. 


$$
T E C H_{s, t}=\frac{\sum_{j=-9}^{0} I N V E S T_{s, t+j}}{\sum_{j=-2}^{+2} A R B V_{s, t+j}}
$$

waarbij:

$I_{\text {INVEST }}, \quad=$ de investeringen in bedrijfstak $\mathrm{s}$ in jaar $\mathrm{t}$ in prijzen van 1980.

$A R B V_{s, t} \quad=$ het arbeidsvolume in 1000 mensjaren in sector $\mathrm{s}$ in jaar $\mathrm{t}$.

De invloed van bedrijfstakspecifieke conjuncturele factoren, wordt in navolging van Dekker c.s., weergegeven door een indicator van de bezettingsgraad van de produktiecapaciteit. De variabele is als volgt gedefinieerd:

$$
B E Z_{s, t}=\frac{T W_{s, t}}{\frac{1}{5} \sum_{j=-2}^{+2} T W_{s, t+j}}
$$

waarbij:

$T W_{s, t}=$ de toegevoegde waarde in sector $s$ in jaar $t$ in prijzen van 1980

De hoogte van het arbeidsvolume heeft een structureel effect op het aantal leerovereenkomsten. Deze variabele geeft inzicht in de omvang van de totale gerealiseerde arbeidsvraag van de desbetreffende bedrijfssector. Vanwege de te verwachten multicollineairiteitsproblemen is er voor gekozen om het aantal leerovereenkomsten te schalen met het arbeidsvolume. Vanuit de aannemelijke veronderstelling dat het aantal leerovereenkomsten in een bepaalde bedrijfssector recht evenredig verandert met de omvang van de werkgelegenheid in de desbetreffende sector, kan het aantal leerovereenkomsten als volgt worden gespecificeerd:

$T_{s, t}=W_{s, t} * F\left(X_{s, t}, \theta_{s}\right)$

ofwel:

$Y_{s, t}=\frac{T_{s, t}}{W_{s, t}}=F\left(X_{s, t} \theta_{s}\right)$

met:

$T_{s, t} \quad=$ totaal aantal leerovereenkomsten in sector $\mathrm{s}$ in jaar $\mathrm{t}$

$W_{s, t} \quad=$ arbeidsvolume in sector $\mathrm{s}$ in jaar $\mathrm{t}$

$Y_{s, t} \quad=$ aantal leerovereenkomsten in verhouding tot het arbeidsvolume in sector $s$ en jaar $\mathrm{t}$

$F($...) $\quad=$ functie van verklarende variabelen en parameters

$X_{s, t} \quad=$ matrix van verklarende variabelen voor sector $\mathrm{s}$

$\theta_{s} \quad=$ vector van parameters voor sector $\mathrm{s}$ 
Verondersteld wordt dat de vraagfactoren een optimale waarde van de endogene variabele bepalen, maar dat in één periode slechts een bepaalde fractie $\pi$ van de gewenste aanpassing plaats vindt. Dit partiële aanpassingsmechanisme kan worden gezien als het gevolg van gewoontevorming ('habit formation') in het aanbod van praktijkplaatsen door bedrijven. Dit betekent dat niet alleen de actuele economische omstandigheden, maar ook de vraag naar leerlingen in het verleden van belang is. Zo is het bijvoorbeeld denkbaar dat het afbreken van opleidingscapaciteit, die in het verleden gecreëerd is, meer kosten met zich meebrengt dan het tijdelijk in stand houden van deze opleidingscapaciteit, ondanks de tijdelijk afgenomen vraag naar leerlingen. Dit proces van partiële aanpassing, kan als volgt worden gemodelleerd (Judge cs., 1980):

$Y_{t}^{*}=F\left(X_{t}, \theta\right)+v_{t}$

waarbij $v_{t}$ een storingsterm is.

In vergelijking (8) komt tot uitdrukking dat het optimale aandeel van leerovereenkomsten in het arbeidsvolume volledig wordt bepaald door determinanten van de vraag.

$Y_{t}-Y_{t-1}=\pi *\left(Y_{t}^{*}-Y_{t-1}\right)$

In (9) komt tot uitdrukking dat de feitelijk gerealiseerde verandering van het aantal leerovereenkomsten in verhouding tot het arbeidsvolume in een bepaald jaar slechts een gedeelte $(\pi)$ betreft van de in feite gewenste aanpassing.

Substitutie van (8) in (9) leidt tot een schattingsmodel met een vertraagde endogene variabele:

$Y_{t}=\pi * F\left(X_{t}, \theta\right)+(1-\pi) * Y_{t-1}+\pi * v_{t}$

\subsection{Econometrische modellering}

Doorgaans wordt een logaritmische transformatie gekozen ten einde negatieve waarden van het aandeel $Y_{t}$ en problemen van heteroscedasticiteit te vermijden. Op basis van een aantal schattingen en het criterium van Box en Cox is gebleken dat een logaritmische transformatie inderdaad de voorkeur verdient boven een lineair verband ${ }^{4}$. De vergelijking die per sector wordt

4. Box en Cox hebben een procedure ontwikkeld om op basis van de data een geschikte functionele vorm te kiezen. In deze procedure wordt allereerst de endogene variabele $Y_{t}$ getransformeerd tot een variabele $Y_{t}(\mu)=\left(Y_{t}^{\mu}-1\right) / \mu \dot{Y}^{\mu-1}$, waarbij $\dot{Y}=\left(\prod_{t=1}^{n} Y_{t}\right)^{1 / n}$. Vervolgens wordt deze getransformeerde endogene geregresseerd op de exogenenen voor verschillende waarden van $\mu$. Uiteindelijk wordt voor $\mu$ een waarde gekozen die de residuele kwadratensom minimaliseert. Voor de schattingen in dit onderzoek zijn alleen de waarden $\mu=1$ (originele data) en $\mu=0$ (logaritmische transformatie) met elkaar vergeleken. 
geschat luidt aldus:

$$
\begin{aligned}
\log \left(Y_{s, t}\right)= & \theta_{1}+\theta_{2} * \log \left(Y_{s, t-1}\right)+\theta_{3} * \log \left(T E C H_{s, t}\right)+\theta_{4} * \log \left(B E Z_{s, t}\right)+ \\
& \theta_{5} * \log \left(B V J_{t}\right)+u_{s, t}
\end{aligned}
$$

met: $\begin{aligned} & Y_{s, t}=\frac{T_{s, t}}{W_{s, t}} \quad= \text { aandeel } \text { van het totaal aantal leerovereenkomsten in het arbeidsvolume in } \\ & \text { sector } \mathrm{s} \text { in jaar } \mathrm{t}\end{aligned}$

$T_{s, t} \quad=$ totaal aantal leerovereenkomsten in sector $\mathrm{s}$ in jaar $\mathrm{t}$

$W_{s, t} \quad=$ arbeidsvolume in 1000 mensjaren in sector $\mathbf{s}$ in jaar $\mathbf{t}$

$\mathrm{TECH}_{s, t} \quad=$ kapitaal-arbeidsratio in sector $\mathrm{s}$ in jaar $\mathrm{t}$

$B E Z_{s, t} \quad=$ bezettingsgraad in bedrijven in sector $\mathrm{s}$ in jaar $\mathrm{t}$

$B V J_{t} \quad=$ omvang subsidie volgens de BVJ-regeling in jaar $\mathrm{t}$

$u_{s, t} \quad=$ storingsterm, standaard normaal verdeeld, uitgezonderd in de sectoren waarin eerste orde autocorrelatie is geconstateerd.

Er is ook onderzocht of er sprake is van eerste orde autocorrelatie. Vanwege het feit dat een vertraagde endogene in de vergelijking is opgenomen, kan de Durbin en Watson toets niet gebruikt worden. $\mathrm{Er}$ is daarom een alternatieve procedure gevolgd om eventueel het optreden van eerste orde autocorrelatie te achterhalen ${ }^{5}$. Voor een aantal sectoren is geconstateerd dat er sprake is van eerste orde autocorrelatie. In de schattingsvergelijking voor deze sectoren is derhalve een parameter voor eerste orde autocorrelatie opgenomen.

5. De meest geëigende methode om eerste orde autocorrelatie te berekeken voor een vergelijking met een vertraagde endogene is het berekenen van Durbin's $h$. Deze grootheid kan echter niet in alle gevallen worden berekend. $\mathrm{Er}$ is daarom gekozen voor een procedure die asympotisch identiek is. De methode (Judge cs., 1988) bestaat hieruit dat de residuen van de vergelijking worden geregresseerd op de vertraagde residuen en de overige verkarende variabelen (inclusief de vertraagde endogene). Indien de parameter van de vertraagde residuen significant van nul verschilt, behoort een term voor eerste orde autocorrelatie in de oorspronkelijke vergelijking te worden opgenomen. 


\section{SCHATTINGSRESULTATEN}

\subsection{Inleiding}

In dit hoofdstuk worden de resultaten van de schatting van vergelijking (11) besproken. Eerst worden in paragraaf 3.1. de resultaten voor de primaire leerovereenkomsten behandeld. Daarnaast wordt in paragraaf 3.2. ingegaan op de resultaten voor de voortgezette leerovereenkomsten. Vervolgens wordt in paragraaf 3.3. voor iedere sector afzonderlijk nagegaan in hoeverre de uitkomsten voor de primaire en voortgezette leerovereenkomsten van elkaar afwijken.

$\mathrm{Er}$ is bij de analyses nagegaan of er sprake is van ernstige multicollineairiteit tussen de verschillende determinanten van de vraag. Op basis van de conditiegetallen is geconstateerd dat er in een aantal sectoren sprake is van multicollineairiteit. Daarom is voor én sector, de metaalsector, door middel van 'ridge regression ${ }^{6}$ ' onderzocht of de schattingsresultaten sterk vertekend kunnen zijn vanwege multicollineairiteit tussen de variabelen. De geschatte parameters en de significantie van de parameters blijken echter volgens deze schattingstechniek weinig te verschillen van de hier gepresenteerde schattingen. Ook is geprobeerd de multicollineairiteitsproblematiek te ondervangen door na te gaan of lineaire transformaties van de vraagfactoren andere uitkomsten te zien gaven. Deze methode, die gezien kan worden als een vorm van principale componenten-analyse, gaf betere conditiegetallen en lagere correlaties. De schattingen weken desalniettemin eveneens weinig af van de hier gepresenteerde schattingen.

Op basis van deze resultaten kan worden geconcludeerd dat multicollineairiteit welliswaar een rol speelt, maar dat de parameterwaarden en de siginificantie van de parameters hierdoor niet sterk worden vertekend. Er zijn derhalve geen schattingstechnieken toegepast om te corrigeren voor multicollineairiteit.

\subsection{Primaire leerovereenkomsten}

De schattingsresultaten voor de primaire leeerovereenkomsten worden weergegeven in tabel 3.1. De vertraagde endogene variabele is bij het merendeel van de sectoren significant, waarbij de parameterwaarde per sector globaal varieert tussen de 0.5 en de 0.8 . De fractie $\pi$ varieert

6. 'Ridge regression' is een schattingstechniek die gebruikt kan worden als de matrix $X^{\prime} X$ singulier of bijna singulier is, hetgeen het geval is bij ernstige multicollineairiteit. Voor het berekenen van de parameters wordt niet bovengenoemde matrix geïnverteerd, maar de matrix $\left[X^{\prime} X+k * I_{n}\right]$. $k$ wordt op basis van een Bayesiaans criterium gekozen (Hall, 1987). 
derhalve van 0.2 tot 0.5 . Dit houdt in dat gewoontevorming in de vraag naar leerovereenkomsten een belangrijke rol speelt: per jaar vindt minder dan de helft van de gewenste aanpassing plaats.

Tabel 3.1. Schattingsresultaten primaire leerovereenkomsten

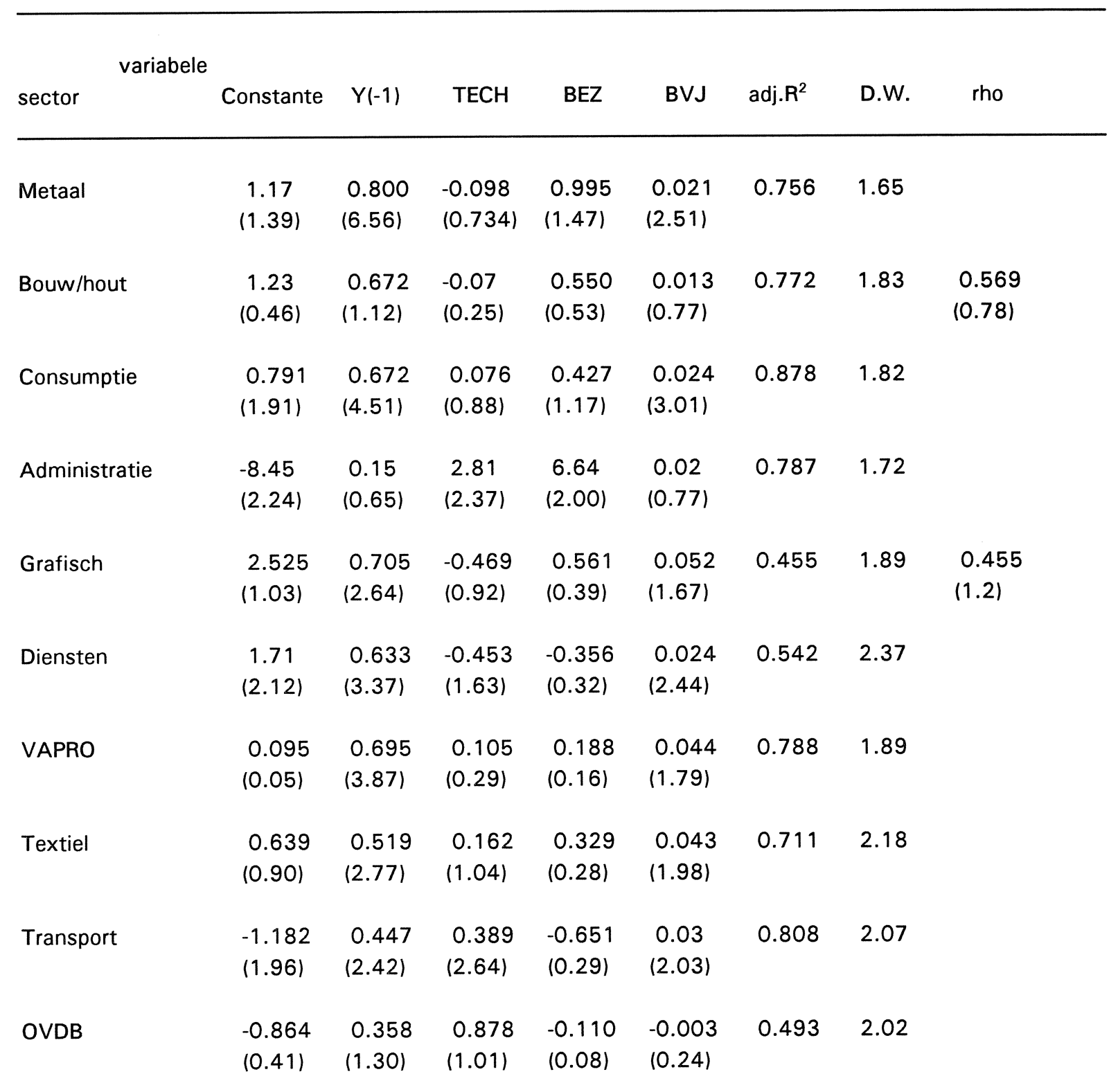

De parameter voor de technologie-variabele (kapitaal-arbeidratio) is significant in de transportsector en de adminstratieve sector. De parameters hebben een positief teken. Dit betekent dat naarmate er in deze bedrijfssectoren arbeid door kapitaal wordt vervangen er een relatief grotere vraag naar leerovereenkomsten ontstaat (in procenten van het arbeidsvolume). Hieruit kan worden geconcludeerd dat in die sectoren de technologische ontwikkelingen leiden tot een 
toename van de vraag naar geschoolde vakmensen.

De conjunctuur-variabele is alleen significant in de administratieve sector. Het teken van de parameter is in overeenstemming met de verwachtingen positief. Het is echter, gezien het beeld zoals dat in figuur 1 werd geschetst, opvallend dat deze variabele in de meeste sectoren niet significant is. De correlaties tussen deze variabele en de andere variabelen zijn erg laag, zodat multicollineairiteit uitgesloten is.

De BVJ beleidsvariabele is significant in diverse sectoren: metaal, consumptie, diensten, transport en textiel. Het teken van de parameter is positief, hetgeen in overeenstemming is met de verwachting dat een hogere vergoeding per praktijkplaats tot een stijging van het aantal leerovereenkomsten leidt. Wel moet daarbij worden opgemerkt dat de invloed van de BVJ beleidsvariabele beperkt is. Dit wordt duidelijk als men de waarden van de parameters als elasticiteiten opvat. Wanneer de subsidie met $1 \%$ zou stijgen, zou het aantal primaire leerovereenkomsten in de metaalsector met $0,02 \%$ stijgen en op lange termijn met nog slechts $0,02 / 0,20=0,11 \%$. Voor de andere sectoren waar deze variabele significant is varieert de lange termijn elasticiteit tussen 0,05 en $0,09 \%$.

De verklaarde variantie van de vergelijking is in de meeste sectoren circa 0.7. Dit houdt in dat de exogenen de variatie in de endogenen redelijk verklaren. Wel is deze hoge verklaarde variantie voor een belangrijk deel toe te schrijven aan de vertraagde endogene en - in sommige gevallen - de autoregressieve parameter voor eerste orde autocorrelatie, opgenomen in de vergelijkingen voor de bouw- en houtsector en de grafische sector.

\subsection{Voortgezette leerovereenkomsten}

De schattingsresultaten van de voortgezette leerovereenkomsten zijn weergegeven in tabel 3.2. De vertraagde endogene is bij het merendeel van de sectoren significant, waarbij de parameterwaarde varieert tussen de 0.34 en de 0.92. De jaarlijkse partiële aanpassing varieert derhalve tussen de 0.08 en de 0.66 . Ook voor de meeste voortgezette leerovereenkomsten is er dus sprake van geleidelijke aanpassing. Voor twee sectoren, de administratieve en de dienstensector, zijn de coëfficiënten voor de vertraagde endogenen echter niet significant, zodat geconcludeerd kan worden dat de vraag in deze sectoren niet via partiële aanpassingen, maar direct reageert op economische ontwikkelingen.

De technologie-variabele is significant in de metaal-, de consumptieve, de diensten- en de administratieve sector. De desbetreffende parameters hebben, op die voor de dienstensector na, een positief teken. De interpretatie hiervan is analoog aan de interpretatie bij de primaire leerovereenkomsten: een toenemende intensivering van de techniek vereist in deze gevallen meer geschoolde vakmensen. 
Tabel 3.2. Schattingsresultaten voortgezette leerovereenkomsten

\begin{tabular}{|c|c|c|c|c|c|c|c|c|}
\hline \multicolumn{2}{|c|}{ variabele } & \multirow[b]{2}{*}{$Y(-1)$} & \multirow[b]{2}{*}{$\mathrm{TECH}$} & \multirow[b]{2}{*}{ BEZ } & \multirow[b]{2}{*}{ BVJ } & \multirow[b]{2}{*}{ adj. $R^{2}$} & \multirow[b]{2}{*}{ D.W. } & \multirow[b]{2}{*}{ rho } \\
\hline Sector & Constante & & & & & & & \\
\hline \multirow[t]{2}{*}{ Metaal } & -2.800 & 0.458 & 1.109 & -3.32 & 0.077 & 0.889 & 2.04 & \\
\hline & $(1.70)$ & $(2.41)$ & $(2.02)$ & $(2.59)$ & $(0.49)$ & & & \\
\hline \multirow[t]{2}{*}{ Bouw/hout } & -0.02 & 0.918 & 0.067 & -0.22 & 0.006 & 0.741 & 1.38 & \\
\hline & $(0.03)$ & $(5.36)$ & $(0.44)$ & $(0.21)$ & $(0.39)$ & & & \\
\hline \multirow[t]{2}{*}{ Consumptie } & -1.185 & 0.459 & 0.623 & 1.353 & -0.004 & 0.89 & 2.34 & \\
\hline & $(2.58)$ & $(3.00)$ & $(3.61)$ & $(2.52)$ & $(0.035)$ & & & \\
\hline \multirow[t]{2}{*}{ Administratie } & -27.22 & -0.233 & 8.17 & 8.26 & 0.03 & 0.881 & 1.33 & \\
\hline & (3.73) & $(0.86)$ & $(3.74)$ & $(2.02)$ & $(1.02)$ & & & \\
\hline \multirow{2}{*}{ Grafisch } & -6.03 & 0.618 & 1.70 & 2.37 & -0.006 & 0.59 & 2.01 & 0.304 \\
\hline & $(1.82)$ & $(2.1)$ & $(1.2)$ & $(1.6)$ & $(0.2)$ & & & $(0.59)$ \\
\hline \multirow[t]{2}{*}{ Diensten } & -0.717 & -0.09 & -0.958 & -1.15 & -0.02 & 0.115 & 2.27 & \\
\hline & $(0.85)$ & $(0.39)$ & $(2.08)$ & $(0.78)$ & $(1.4)$ & & & \\
\hline \multirow[t]{2}{*}{ VAPRO } & -13.47 & 0.745 & 2.48 & 1.60 & 0.12 & 0.279 & 2.07 & \\
\hline & $(0.90)$ & $(3.16)$ & $(0.89)$ & $(0.30)$ & $(1.67)$ & & & \\
\hline \multirow[t]{2}{*}{ Textiel } & -0.253 & 0.523 & -0.07 & -3.56 & 0.07 & 0.24 & 2.08 & \\
\hline & $(0.14)$ & $(1.32)$ & $(0.128)$ & $(0.76)$ & $(0.94)$ & & & \\
\hline \multirow[t]{2}{*}{ Transport } & 0.851 & 0.75 & -0.276 & 0.883 & 0.046 & 0.561 & 2.10 & \\
\hline & $(0.87)$ & $(3.31)$ & $(1.08)$ & $(0.25)$ & $(2.19)$ & & & \\
\hline \multirow[t]{2}{*}{ OVDB } & -5.358 & 0.339 & 2.200 & -9.79 & 0.07 & 0.911 & 2.74 & \\
\hline & 0.411 & $(1.30)$ & $(0.78)$ & $(2.33)$ & $(1.37)$ & & & \\
\hline
\end{tabular}

De conjunctuur-variabele is significant in de metaal-, de consumptieve, de adminstratieve en de verzorgende sector. De tekens van de parameters zijn echter zowel negatief als positief. Verschillende tekens voor deze variabele wijzen op de mogelijkheid dat tegengesteld gereageerd wordt op de conjunctuur. Een positieve coëfficient wijst op het verwachte positieve verband tussen de bedrijvigheid en het aantal afgesloten leerovereenkomsten. Het niet verwachte negatieve teken voor de coëfficient van de conjunctuur-variabele voor de metaal- en de verzorgende sector zou kunnen wijzen op het verschijnsel dat leerlingen met een leerovereenkomst in een periode van hoogconjunctuur eerder hun opleiding voortijdig beëindigen, vanwege de zuigkracht van de arbeidsmarkt. 
De BVJ beleidsvariabele is bij de voortgezette leerovereenkomsten alleen significant in de transportsector. Het teken van de parameter is positief, hetgeen in overeenstemming is met de verwachting dat een hogere vergoeding per praktijkplaats (lagere loonkosten) tot een stijging van het aantal leerovereenkomsten leidt. Ook hier gaat het echter om een gering kwantitatief effect.

De verklaarde variantie van de vergelijkingen verschilt aanzienlijk. Deze is hoog voor de verzorgende sector, de metaalsector, de consumptieve en de administratieve sector en zeer laag voor de dienstensector, de textielsector en de VAPRO sector. Voor de grafische sector is gecorrigeerd voor eerste orde autocorrelatie.

\subsection{Bespreking van de resultaten per sector}

In de metaalsector hebben de conjunctuur- en de technologievariabele meer verklaringskracht bij de voortgezette leerovereenkomsten dan bij de primaire leerovereenkomsten. Hetzelfde geldt voor de consumptieve sector en de verzorgende sector. Bij de overige sectoren is het beeld voor de primaire en voortgezette leerovereenkomsten vrijwel identiek. Beide variabelen bieden met name een goede verklaring voor het aantal leerovereenkomsten in de administratieve sector. In deze sector lijken bovendien partiële aanpassingsprocessen geen rol te spelen, aangezien de parameter voor de vertraagde endogene niet significant is. Voor deze sector zijn de tekens van de parameters van de conjunctuur- en de technologievariabele in de vergelijking voor de primaire en voortgezette leerovereenkomsten hetzelfde. Opvallend is dat de BVJ-variabele veel vaker significant is bij de primaire leerovereenkomsten, maar niet bij de voortgezette leerovereenkomsten. Dit hangt waarschijnlijk samen met het feit dat deze subsidieregeling met name bedoeld is voor primaire leerovereenkomsten. 


\section{CONCLUSIES}

In deze studie is onderzocht in hoeverre economische determinanten (vraagfactoren) bepalend zijn voor het aantal leerovereenkomsten. In een eerdere studie is onderzocht in hoeverre aanbodfactoren (het aanbod van leerlingen) een rol spelen bij de ontwikkeling van het aantal leerovereenkomsten.

De uitsplitsing van het aantal leerovereenkomsten die in Lodder, De Grip en Heijke (1992) is gemaakt in gecontinueerde, nieuwe en beëindigde leerovereenkomsten, blijkt ook vruchtbaar te zijn om een onderscheid tussen uitbreidings- en vervangingsvraag te kunnen maken. De verandering van het totale aantal leerovereenkomsten is gelijk te stellen aan de uitbreidingsvraag naar leerovereenkomsten. Economische variabelen die de uitbreidingsvraag verklaren kunnen dan gezien worden als een verklaringsgrond voor het totale aantal leerovereenkomsten.

Het beroepenmodel van Dekker, De Grip en Heijke (1992) biedt aanknopingspunten om de determinanten van de vraag te bepalen. In het ontwikkelde model in deze studie is de betekenis van een viertal verklaringsgronden nagegaan. In de eerste plaats is een kapitaal-arbeidsratio gebruikt als indicator voor de technologische ontwikkeling. In de tweede plaats is een proxyvariabele voor de sectoriële bezettingsgraad gebruikt als indicator voor conjuncturele fluctuaties. In de derde plaats is met structurele sector-specifieke factoren rekening gehouden door het aantal leerovereenkomsten te schalen met het arbeidsvolume in de desbetreffende sector. Tenslotte is een kostenvariabele (BVJ-subsidiebedrag per praktijkplaats) gebruikt als indicator voor de prijs van arbeid.

Bij de specificatie van het model is rekening gehouden met de mogelijkheid dat er sprake is van een proces van partiële aanpassing. Dit houdt in dat de exogene variabelen weliswaar een optimale waarde van de endogene bepalen, maar dat in een bepaald jaar slechts een gedeelte van de aanpassing wordt gerealiseerd. Een dergelijke proces kan gemodelleerd worden door een vertraagde endogene variabele toe te voegen. Daarnaast is geconstateerd dat er in een in aantal sectoren sprake is van eerste orde autocorrelatie. Voor deze sectoren is een parameter voor eerste orde autorcorrelatie toegevoegd.

Bij het schatten van het model is het vermoeden ontstaan dat er sprake is van multicollineairiteit. Door middel van daarvoor geëigende procedures is onderzocht of deze multicollineairiteit de onderzoeksresultaten ernstig verstoort. Dit blijkt niet het geval te zijn.

De variabele die als indicator voor het optreden van conjuncturele factoren in het model is opgenomen blijkt slechts in een aantal sectoren significant te zijn. Dit strookt niet met de algemene gedachte dat de markt voor leerovereenkomsten conjunctuurgevoelig is. Bij vervolg- 
onderzoek zou een andere modellering mogelijk tot meer inzicht in deze kwestie kunnen leiden. De variabele die als indicator voor de technologische ontwikkeling is gebruikt, heeft eveneens in slechts een gering aantal sectoren een significante invloed. De BVJ-beleidsvariabele is daarentegen significant in een groot aantal sectoren in het primaire leerlingwezen en heeft in die gevallen het verwachte positieve teken. Desalniettemin is de kwantitatieve betekenis van de subsidieregeling relatief gering. De vertraagde endogene is in vrijwel iedere sector significant. Dit impliceert dat geleidelijke aanpassingsprocessen c.q. gewoontevorming ('habit formation') doorgaans een zeer belangrijke rol spelen.

De conclusie met betrekking tot het model met vraagfactoren is dat voor de meeste sectoren gewoontevorming bij bedrijven een belangrijke rol speelt in de vraag naar leerovereenkomsten. Andere factoren, zoals de bezettingsgraad in bedrijven en de kapitaal-arbeidsratio spelen in mindere mate een rol. De vergoedingen die plaatsvinden in het kader van de BVJ-regeling blijken met name de vraag naar primaire leerovereenkomsten te beïnvloeden. Bij de administratieve sector is geconstateerd dat er sprake is van conjunctuurgevoeligheid. Ook stijgt in deze sector de vraag naar leerovereenkomsten bij een stijging van de kapitaal-arbeidsratio. In deze sector speelt gewoontevorming echter geen rol.

Bij de interpretatie van deze schattingsresultaten moet worden bedacht dat er getracht is een verklaring te vinden voor het aandeel dat de leerovereenkomsten uitmaken van het arbeidsvolume. Hoewel de gevonden resultaten beperkt zijn, betekent dit niet dat economische factoren geen enkele rol spelen bij het afsluiten van leerovereenkomsten. Voorzover het aantal leerovereenkomsten varieert met het arbeidsvolume zijn de variabelen die de totale arbeidsvraag c.q. gerealiseerde werkgelegenheid bepalen ook van invloed op het aantal leerovereenkomsten. Er kan evenwel geconstateerd worden dat de onderzochte economische determinanten nauwelijks (extra) invloed uitoefenen op de mate waarin de vraag naar arbeid wordt gerealiseerd in de vorm van leerlingplaatsen.

Met betrekking tot de in de inleiding genoemde mogelijkheid van het schatten van een model waarin zowel aanbod- als vraagfactoren zijn opgenomen, moet worden geconstateerd dat het niet zinvol lijkt om variabelen als de bezettingsgraad (conjunctuur-indicator) en de kapitaalarbeidsratio als vraagfactoren op te nemen in een vergelijking waarin de leerovereenkomsten zijn uitgedrukt als aandeel van het sectorale arbeidsvolume. In de meeste sectoren hebben deze variabelen immers geen significante invloed op de ontwikkeling van het aantal leerovereenkomsten als percentage van het arbeidsvolume. Bovendien kleven er aan het schatten van dergelijke modellen een groot aantal bezwaren die hun praktische bruikbaarheid waarschijnlijk sterk zal beperken. 


\section{LITERATUUR}

Centraal Planbureau (1990), Centraal Economisch Plan, Den Haag.

Dekker, R.J.P., A. de Grip, J.A.M. Heijke (1990), An Explanation of the Occupational structure of Sectors of Industries in: Labour, vol.4, nr. 3, winter 1990, pp. 3-31.

Directoraat Generaal voor de Arbeidsvoorziening (1990), Voortgangsrapportage BVJ 1989/1990, Den Haag.

Frietman , J., B.W.M. Hövels (1990), Leerlingwezen als opleidingsweg in en van het bedrijfsleven, in: Jeugd en samenleving, oktober $1990-10$.

Galan, C., de (1981), Economie van de arbeid, Samsom, Alphen aan den Rijn.

Grip, A., de, J.A.M. Heijke, R.J.P. Dekker (1989), De arbeidsmarkt naar opleiding en beroep in 1992, ROA-R-1989/8, Maastricht.

Hall, B.H., Schnake, R., Cummins, C. (1987), TSP User's Manual, TSP International, Palo Alto.

Hövels, B.W.M. (1985), Arbeidsorganisaties en het leerlingwezen, een onderzoek naar het aanbod van leer-arbeidsplaatsen door arbeidsorganisaties, Ministerie van Sociale Zaken en Werkgelegenheid, Den Haag.

Judge, G.G., W.E. Griffiths, R. Carter Hill, T.C. Lee (1980), The theory and practice of econometrics, Wiley \& Sons, Toronto.

Kooiman, P., T. Kloek (1979), Aggregation of micro markets in disequilibrium, theory and application to the Dutch Labour Market 1948-1975, Erasmus Universiteit, Rotterdam.

Lodder, B.J.H., A. de Grip, J.A.M. Heijke (1992), In- en uitstroom op de markt voor leerovereenkomsten, ROA-RM-1992/1, Maastricht.

Maddala, G.S. (1983), Limited-dependent and qualitative variables in econometrics, Cambridge, University Press, Cambridge.

Ministerie van Sociale Zaken en Werkgelegenheid (1990), Brief van de minister van Sociale Zaken aan de Tweede Kamer, vergaderjaar 1989-1990, 21 314, nrs 1-2.

Ministerie van Sociale Zaken en Werkgelegenheid (1985), Educatie in CAO's, Den Haag.

Oosterbeek, H., C.N. Teulings, H.D. Webbink (1991), Het voorspellen van de vraag naar hoger onderwijs, in: J.K. Koppen, H. Stroomberg, M. van der Kamp, Hoger onderwijs en volwasseneneducatie; Onderwijsresearchdagen '91, SCO, Amsterdam.

Peeters, H.M.M. (1990), An explanation of the occupational and educational structure of employment by means of multinomial logit, ROA-W-1990/4E, Maastricht.

SAS/ETS (1988), User's Guide, Versie 6, 1e editie, SAS Institute Inc, Cary, NC. 